\title{
Why are some people (and countries) more protectionist than others?
}

\author{
Anna Maria Mayda ${ }^{\mathrm{a}}$, Dani Rodrik ${ }^{\mathrm{b}, *}$ \\ ${ }^{a}$ School of Foreign Service and Department of Economics, Georgetown University, \\ Washington, DC 20057, USA \\ ${ }^{\mathrm{b}}$ Kennedy School of Government, Harvard University, \\ Cambridge, MA 02138, USA
}

Received 1 April 2002; accepted 7 December 2003

\begin{abstract}
We analyze two cross-country data sets that contain information on attitudes toward trade as well as a broad range of socio-demographic and other indicators. We find that pro-trade preferences are significantly and robustly correlated with an individual's level of human capital, in the manner predicted by the factor endowments model. Preferences over trade are also correlated with the trade exposure of the sector in which an individual is employed: individuals in non-traded sectors tend to be the most pro-trade, while individuals in sectors with a revealed comparative disadvantage are the most protectionist. Third, an individual's relative economic status has a very strong positive association with pro-trade attitudes. Finally, non-economic determinants, in the form of values, identities, and attachments, play an important role in explaining the variation in preferences over trade. High degrees of neighborhood attachment and nationalism/patriotism are associated with protectionist tendencies.
\end{abstract}

(C) 2004 Elsevier B.V. All rights reserved.

\section{JEL classification: $\mathrm{F} 1$}

Keywords: Trade; Policy preferences; Political economy

\section{Introduction}

Economists disagree intensely on many public policy issues. What is the best way to deal with poverty? What is the appropriate role of the government in providing health insurance? Is it good anti-trust policy to break up Microsoft? Does counter-cyclical macroeconomic policy make sense? Should social security be privatized? Should we

\footnotetext{
* Corresponding author. Tel.: +1-617-495-9454.

E-mail addresses: amm223@georgetown.edu (A.M. Mayda), dani_rodrik@harvard.edu (D. Rodrik).
} 
tax international capital flows? Is the minimum wage desirable? In these and many other areas, economists are engaged in lively controversies that reflect broader public debates on social problems.

International trade poses an interesting contrast. Here the debates remain largely technical, even among policy-oriented economists: Which theory is more appropriate in explaining the patterns of trade? How much, if at all, has trade contributed to the rise in the skill premium in the U.S.? Why are "border effects" so large? On the important policy questions that excite the public, there is virtually no difference of views. In particular, there exists near-universal consensus among mainstream economists on the desirability of free trade (see for example Alston et al., 1992).

It is striking how little this consensus resonates with public opinion. When asked about their views on trade, approximately $60 \%$ of respondents in opinion polls express anti-trade views. ${ }^{1}$ While there are some interesting differences across countries, which we shall document and analyze later, a majority of respondents tend to be in favor of restricting trade in most countries. Our purpose in this paper is to shed light on this phenomenon, by undertaking a systematic analysis of individual attitudes towards trade and their underlying determinants. We make use of two cross-country surveys of individual opinions. The first of these comes from the International Social Survey Programme (ISSP), and it allows us to perform a comparative analysis covering more than 28,000 individuals in 23 countries. We use as our dependent variable a question in the ISSP data set that asks whether the respondent favors restricting trade. The data set also contains a wealth of information on demographics, socio-economic status, and values, which we use to test a number of hypotheses about the formation of attitudes. To ascertain the robustness of our findings, we also run parallel tests whenever possible with the third wave of the World Values Survey (WVS), which covers a larger sample of countries.

The standard workhorse models of international trade have well-defined implications for the distributive consequences of trade and hence for individual attitudes (see Rodrik (1995) for a review of the literature). Under the factor-endowments model, which assumes costless inter-sectoral mobility of productive factors, trade benefits individuals who own the factors with which the economy is relatively well endowed, and hurts the others. This is the well-known Stolper-Samuelson theorem. Under the specific-factors model, trade benefits individuals who are employed in the export-oriented sectors and hurts those who are employed in the import-competing sectors. To the extent that individuals are motivated by material self-interest, these models provide important hints about an individual's likely attitude to trade depending on his/her factor type or sector of employment.

Our first set of results directly relates to these economic models. Most strikingly, we find strong support for the factor-endowments view of the world in both the ISSP and WVS data sets. Individuals with higher levels of human capital (proxied by educational attainment or occupational categories) oppose trade restrictions, but only in countries that are well endowed with human capital. In the ISSP data set, higher

\footnotetext{
${ }^{1}$ The fraction of individuals who are against trade (i.e., in favor of limiting imports of foreign products) ranges from $55 \%$ in the ISSP data set to $60 \%$ in the WVS data set.
} 
levels of education are associated with pro-trade views in advanced countries such as Germany and the United States, but with anti-trade views in the Philippines (the poorest country in the ISSP sample). We find a very similar pattern in the WVS data set, which has the advantage for this purpose that it covers many more developing countries (including very poor countries such as Nigeria and Bangladesh). Regardless of whether skill is measured by educational attainment or occupation-based skill levels, the estimated impact of skill on pro-trade attitudes in the WVS data set is strongly positive in the richest countries, but weak or negative in the poorest. That individual trade opinions interact with country characteristics in exactly the manner predicted by the factor-endowments model in both data sets may be considered surprising, but it is a robust result and perhaps our strongest single finding.

We find support for the specific-factors model as well. In particular, individuals employed in import-competing industries are more likely to be in favor of trade restrictions (compared to individuals in non-traded sectors). Individuals in export-oriented sectors are not significantly more likely to oppose import restrictions (compared again to individuals in non-traded sectors). This finding can be rationalized within the specific-factors model by appealing to the presence of intra-industry (two-way) trade and myopic behavior on the part of individuals in CA sectors (given how the trade question is phrased in the surveys).

The fact that the factor-endowments and specific-factors models both find support in the data suggests that individuals may differ in the time horizon they use to evaluate trade policy. We find evidence that some think in terms of the long run (and express trade opinions in line with the factor-endowments model), while others think in terms of both the long run and the short run (and express trade opinions in line with both the factor-endowments and the specific-factors model).

While the implications of conventional economic models are borne out by the data, these models go only part of the way in explaining the formation of attitudes. We find that social status, relative incomes, values, and attachments play, if anything, a more important role. For example, individuals who consider themselves part of the upper classes tend to be more favorable to trade than those who consider themselves to be from the lower classes. Individuals with higher relative incomes are more likely to favor trade than those with low relative incomes. Also, protectionist attitudes go together with a well-defined set of normative attributes. Individuals who favor trade restrictions tend to have high attachments to their neighborhood and community, have a high degree of national pride, and believe that national interest should be paramount in making trade-offs. At the same time, individuals who have confidence in their country's democracy are less likely to favor trade protection. In other words, communitarian-patriotic values tend to foster protectionist attitudes, but this tendency is moderated when the broader institutions of society are perceived to be working well.

Our bottom line is that both economic and non-economic considerations are important in determining attitudes towards trade. Once we take the myriad factors discussed above into account, we are reasonably successful in explaining the variation in trade opinions in our sample. Our preferred "combined" model accounts for about a fifth of the sample variance. Moreover, we are also reasonably successful in explaining the differences in mean attitudes across countries. Our preferred model does a good job in explaining 
why respondents in Poland, for example, are more protectionist on average than those in Germany.

The empirical literature on the political economy of trade policy is not small, but it has focused largely on testing the implications of the factor-endowments and specific-factors models in a single country. Studies that have found support for the factor-endowments model include Rogowski (1987, 1989), Midford (1993), Beaulieu (1996), Balistreri (1997), and Scheve and Slaughter (2001a, 2001b). Studies that have found support for the specific-factors model include Magee (1978) and Irwin (1994, 1996). Some have found support for both views of the world (Baldwin and Magee, 1998; Beaulieu and Magee, 2001). With the exception of Balistreri (1997) and Scheve and Slaughter (2001a), none of these studies analyze individual attitudes directly. Instead they infer trade positions from aggregated information on voting, campaigncontributions, or policy outcomes. ${ }^{2}$

Since we began our work with the ISSP data set we have become aware of two other related, but independent papers: O'Rourke and Sinnott (2001) and Beaulieu et al. (2003). Both of these papers only use the ISSP survey to explore the determinants of trade attitudes. Thus, they mainly focus on countries at the high end of the world income and skill distribution. In addition, neither paper tests the specific-factors model. The O'Rourke and Sinnott paper is closest to ours, and many of its conclusions parallel to our own findings.

Our paper is also related to a growing literature within economics that examines survey data to analyze the formation of individual preferences. See for example Luttmer (2001) and Alesina and La Ferrara (2001) on preferences for redistribution, and Blanchflower and Oswald (2000) and Alesina et al. (2001) on the determinants of "happiness", and Caplan (2001) on the sources of differences in policy preferences of the lay public and of economists.

The plan of the paper is as follows. In the next section, we briefly describe the data and the methods we have used. Next, we present a series of empirical models highlighting different types of determinants of trade attitudes. In a final section, we put all our results together and comment on the overall fit of our explanatory framework.

\section{Description of the data and empirical approach}

The International Social Survey Programme (ISSP) collects cross-national data on topics that are important for social science research. In this paper we use data from the 1995 ISSP National Identity module (ISSP). The data set covers information at the individual level on some 28,456 respondents from 23 countries, including the United States, Canada, Japan, many Western and Eastern European countries, and one developing country (the Philippines). ${ }^{3}$ For each individual, the data set contains responses on

\footnotetext{
${ }^{2}$ For example, Irwin $(1994,1996)$ looks at the outcomes of the 1906 and 1923 British general elections and interprets them as proxies for voters' opinions on new trade barriers.

${ }^{3}$ See Table 1 for the full list of countries. We consider Germany West and East separately, even though the survey was carried out after their unification, in order to see whether there are important differences between the two.
} 
a variety of topics, ranging from opinions on trade and immigration policy to feelings of patriotism and regional attachment. In addition, the ISSP data set contains information on several economic and demographic variables. Thus the survey allows us to identify both stated attitudes towards trade and individual characteristics that explain trade positions in standard economic models. ${ }^{4}$

In order to measure individual trade-policy attitudes, we focus on survey answers to the following question: "Now we would like to ask a few questions about relations between (respondent's country) and other countries. How much do you agree or disagree with the following statement: (Respondent's country) should limit the import of foreign products in order to protect its national economy." 5 After deleting the "can't choose, don't know" and "NA, refused" responses, we transformed survey questions into the dependent variable Trade Opinion (with answers ranging from $1=$ agree strongly to $5=$ disagree strongly). Higher values of Trade Opinion therefore correspond to attitudes that are more pro-trade and less protectionist.

We also created two binary variables, which we label Pro-Trade Dummy and Against-Trade Dummy. Pro-Trade Dummy is set equal to unity for individuals opposing trade protection (i.e., for those replying "disagree" or "disagree strongly" to the question), and to zero for the rest. Against-Trade Dummy is set equal to unity for individuals favoring trade protection (i.e., for those replying "agree" or "agree strongly" to the question), and to zero for the others. ${ }^{6}$ Since the results based on Pro-Trade Dummy and Against-Trade Dummy are very similar to those with the ordered logits using Trade Opinion, we will present the results based on Pro-Trade Dummy. ${ }^{7}$

Table 1 presents summary statistics for Trade Opinion, Pro-Trade Dummy and Against-Trade Dummy, by country. Several results stand out. First, the ISSP data set shows that protectionist sentiment runs high on average. Taking the 23 countries as a whole, more than half of the respondents agree with the proposition that trade should be restricted (average Against-Trade Dummy $=0.55$ ), while fewer than a quarter disagree (average Pro-Trade Dummy $=0.22$ ). Second, there is quite a large variation in trade attitudes across countries. Netherlands emerges as the country that is the most pro-trade (Pro-Trade Dummy $=0.37$ ) while Bulgaria is the most protectionist (Pro-Trade Dummy $=0.08$ ), regardless of the indicator used. Third, as the last comment indicates, the rankings of the countries are not very sensitive to the measure of trade attitudes.

Are these findings truly reflective of underlying attitudes towards trade? It is well known that survey responses tend to be highly sensitive to framing - the phrasing of the question and the context and order in which it is asked. In this particular case, there

\footnotetext{
${ }^{4}$ Since not all questions are covered in individual country surveys, our regressions will typically not include all 23 countries.

${ }^{5}$ The possible answers to this question are as follows: (1) agree strongly, (2) agree, (3) neither agree nor disagree, (4) disagree, (5) disagree strongly, (8) can't choose, don't know, (9) NA, refused.

${ }^{6}$ Note that these two alternative formulations of the dependent variable do not require us to drop observations corresponding to "can't choose, don't know" or "NA, refused" answers (which are coded as zeros).

${ }^{7}$ Our results are unchanged when we drop "can't choose, don't know" or "NA, refused" observations in the definition of Pro-Trade Dummy.
} 
Table 1

Summary data on individual attitudes towards trade (ISSP data set)

\begin{tabular}{|c|c|c|c|c|c|c|c|c|c|c|c|c|}
\hline \multirow[t]{2}{*}{ Country } & \multicolumn{6}{|c|}{ Trade Opinion } & \multicolumn{2}{|c|}{$\begin{array}{l}\text { Average Trade } \\
\text { Opinion }\end{array}$} & \multicolumn{2}{|l|}{$\begin{array}{l}\text { Pro-Trade } \\
\text { Dummy }\end{array}$} & \multicolumn{2}{|c|}{$\begin{array}{l}\text { Against-Trade } \\
\text { Dummy }\end{array}$} \\
\hline & $\begin{array}{l}\text { Agree } \\
\text { strongly } \\
(1)\end{array}$ & $\begin{array}{l}\text { Agree } \\
(2)\end{array}$ & $\begin{array}{l}\text { Neither } \\
\text { agree nor } \\
\text { disagree (3) }\end{array}$ & $\begin{array}{l}\text { Disagree } \\
(4)\end{array}$ & $\begin{array}{l}\text { Disagree } \\
\text { strongly } \\
(5)\end{array}$ & $\begin{array}{l}\text { Can't choose } \\
\text { (8) NA, } \\
\text { refused (9) }\end{array}$ & & & & & & \\
\hline Germany West & 0.1513 & 0.2371 & 0.1849 & 0.2683 & 0.0952 & 0.0632 & 2.9134 & 3 & 0.3635 & 2 & 0.3885 & 20 \\
\hline Germany East & 0.2598 & 0.3039 & 0.1699 & 0.1732 & 0.0474 & 0.0458 & 2.4178 & 11 & 0.2206 & 13 & 0.5637 & 13 \\
\hline Great Britain & 0.2316 & 0.4017 & 0.1853 & 0.1238 & 0.0142 & 0.0435 & 2.2549 & 16 & 0.1380 & 18 & 0.6333 & 10 \\
\hline Austria & 0.3784 & 0.3198 & 0.1092 & 0.1261 & 0.0387 & 0.0278 & 2.1021 & 20 & 0.1648 & 15 & 0.6981 & 5 \\
\hline Hungary & 0.4540 & 0.2580 & 0.1580 & 0.0690 & 0.0260 & 0.0350 & 1.9171 & 21 & 0.0950 & 22 & 0.7120 & 3 \\
\hline Italy & 0.2578 & 0.3473 & 0.1453 & 0.1609 & 0.0658 & 0.0229 & 2.4163 & 12 & 0.2267 & 11 & 0.6051 & 11 \\
\hline Ireland & 0.2425 & 0.4135 & 0.1087 & 0.1962 & 0.0272 & 0.0121 & 2.3442 & 14 & 0.2233 & 12 & 0.6559 & 7 \\
\hline Netherlands & 0.0512 & 0.2393 & 0.2824 & 0.3193 & 0.0551 & 0.0527 & 3.0925 & 1 & 0.3743 & 1 & 0.2906 & 23 \\
\hline Norway & 0.0910 & 0.2849 & 0.2737 & 0.2279 & 0.0491 & 0.0733 & 2.8481 & 4 & 0.2770 & 5 & 0.3759 & 21 \\
\hline Sweden & 0.1242 & 0.2809 & 0.2924 & 0.1752 & 0.0640 & 0.0633 & 2.7586 & 5 & 0.2392 & 10 & 0.4051 & 19 \\
\hline Czech Republic & 0.2556 & 0.2655 & 0.1773 & 0.1719 & 0.0954 & 0.0342 & 2.5713 & 8 & 0.2673 & 6 & 0.5212 & 15 \\
\hline Slovenia & 0.2403 & 0.2683 & 0.1795 & 0.2046 & 0.0396 & 0.0676 & 2.5010 & 9 & 0.2442 & 9 & 0.5087 & 17 \\
\hline Bulgaria & 0.5357 & 0.2380 & 0.0498 & 0.0326 & 0.0452 & 0.0986 & 1.6837 & 23 & 0.0778 & 23 & 0.7738 & 1 \\
\hline Russia & 0.3558 & 0.2448 & 0.1174 & 0.1502 & 0.0681 & 0.0637 & 2.2844 & 15 & 0.2183 & 14 & 0.6006 & 12 \\
\hline New Zealand & 0.1764 & 0.3423 & 0.1937 & 0.1985 & 0.0499 & 0.0393 & 2.5868 & 7 & 0.2483 & 7 & 0.5187 & 16 \\
\hline Canada & 0.1413 & 0.3169 & 0.2158 & 0.2184 & 0.0603 & 0.0473 & 2.7265 & 6 & 0.2787 & 4 & 0.4582 & 18 \\
\hline Philippines & 0.1275 & 0.5375 & 0.1633 & 0.1517 & 0.0083 & 0.0117 & 2.3685 & 13 & 0.1600 & 16 & 0.6650 & 6 \\
\hline Japan & 0.1409 & 0.1680 & 0.2954 & 0.1497 & 0.1903 & 0.0557 & 3.0852 & 2 & 0.3400 & 3 & 0.3089 & 22 \\
\hline Spain & 0.2121 & 0.5012 & 0.1097 & 0.0925 & 0.0098 & 0.0745 & 2.1212 & 19 & 0.1024 & 21 & 0.7133 & 2 \\
\hline Latvia & 0.5019 & 0.2079 & 0.0987 & 0.0900 & 0.0412 & 0.0603 & 1.8940 & 22 & 0.1312 & 20 & 0.7098 & 4 \\
\hline Slovak Republic & 0.2666 & 0.2875 & 0.1599 & 0.1614 & 0.0857 & 0.0389 & 2.4925 & 10 & 0.2471 & 8 & 0.5540 & 14 \\
\hline Mean & 0.2357 & 0.3122 & 0.1780 & 0.1666 & 0.0548 & 0.0526 & 2.4643 & & 0.2214 & & 0.5480 & \\
\hline Standard deviation & 0.4245 & 0.4634 & 0.3825 & 0.3727 & 0.2275 & 0.2233 & 1.2021 & & 0.4152 & & 0.4977 & \\
\hline
\end{tabular}

Notes: Trade Opinion gives responses to the following question: "How much do you agree or disagree with the following statement: (respondent's country) should limit the import of foreign products in order to protect its national economy." The six columns under Trade Opinion present the fraction of individuals in a country giving each of the six possible answers. Average Trade Opinion is the average of Trade Opinion excluding can't choose (8) and NA, refused (9) answers. Pro-Trade Dummy is coded as follows: Pro-Trade Dummy $=1$ if Trade Opinion $=4$ or 5; 0 if Trade Opinion =1,2,3,8, or 9. Against-Trade Dummy is coded as follows: Against-Trade Dummy $=1$ if Trade Opinion $=1$ or 2 ; 0 if Trade Opinion $=3,4,5,8$, or 9. The second column of each variable gives the ranking of countries according to that variable. Bold numbers correspond to highest and lowest values. Mean and standard deviation are across individuals in the full sample. 
is especially cause to worry because the question in the ISSP survey refers to possible benefits of restricting imports ("protecting national economy") without mentioning any drawbacks. One would suspect that this imparts a strong protectionist bias to the responses. There are two countervailing considerations. First, there is ample evidence from the U.S., which suggests that the precise phrasing of the question on imports does not greatly affect the average responses provided (see the review in Scheve and Slaughter (2001b)). Second, in our empirical work, we will be interested in identifying the determinants of the differences in attitudes across individuals. Even though the responses on trade may be biased in one direction, our results will not be affected as long as the bias is uniform across individuals (i.e., each individual in a given country expresses a less pro-trade view than otherwise by an equal amount).

A related question concerns the bias that may arise from the fact that individuals in the various countries face different policy environments and economic contexts. Cross-country differences in attitudes towards trade may be shaped by these variations. ${ }^{8}$ We will include a full set of country dummies in our regressions to pick up any spurious correlation between the regressors and the dependent variable. To the extent that such contextual effects affect all individuals in a country in a similar manner, the country dummies will sweep them up. For example, if a given country is caught in a recession and respondents tend to be more protectionist than in normal times, this will be reflected in the estimated coefficient of the country fixed effect. With few exceptions, the inclusion of country fixed effects did not affect the results. On occasion, there may be reason to believe that country characteristics will affect individuals differentially. When such concerns arise, we shall also interact relevant country characteristics with individual attributes.

We might wonder whether protectionist sentiment, as captured by surveys of this kind, has any relationship to actual trade policies. There are of course good reasons to believe that in any political system there would be considerable slippage between individual preferences on any specific issue and policy outcomes. The "supply" side of policy can be as important as the "demand" side. Moreover, the institutional structures of government and of political representation mediate between individual voters and policy makers (Rodrik, 1995). Nonetheless, it is interesting to know whether trade attitudes broadly correlate with trade policies.

Fig. 1 shows that the answer is broadly yes. The correlation between average values of Trade Opinion and average levels of trade duties across countries is negative and statistically significant (robust $t$-statistic $=-2.13$, significant at $5 \%$ level). ${ }^{9}$ The point estimate suggests that a one-point increase in Trade Opinion on our 5-point scale is accompanied by a 3.6 percentage point reduction in average duties. At the same time, it is clear from the figure that the relationship is quite a loose one: the average values

\footnotetext{
${ }^{8}$ Luttmer (2001), for example, shows that individual preferences for redistribution are shaped in part by an "exposure" effect - the extent of welfare recipiency in the respondent's own community.

${ }^{9}$ Trade duties refer to combined import and export duties ( $t_{m}$ and $t_{x}$, respectively) over the 1992-1998 period, calculated as $\left[\left(1+t_{m}\right)^{*}\left(1+t_{x}\right)\right]-1$. The source for duties is the World Development Indicators CD-Rom of the World Bank. Two countries, Slovenia and Slovak Republic, are not included in Fig. 1 because the World Bank does not provide data on duties for them.
} 
average trade duties1992-98

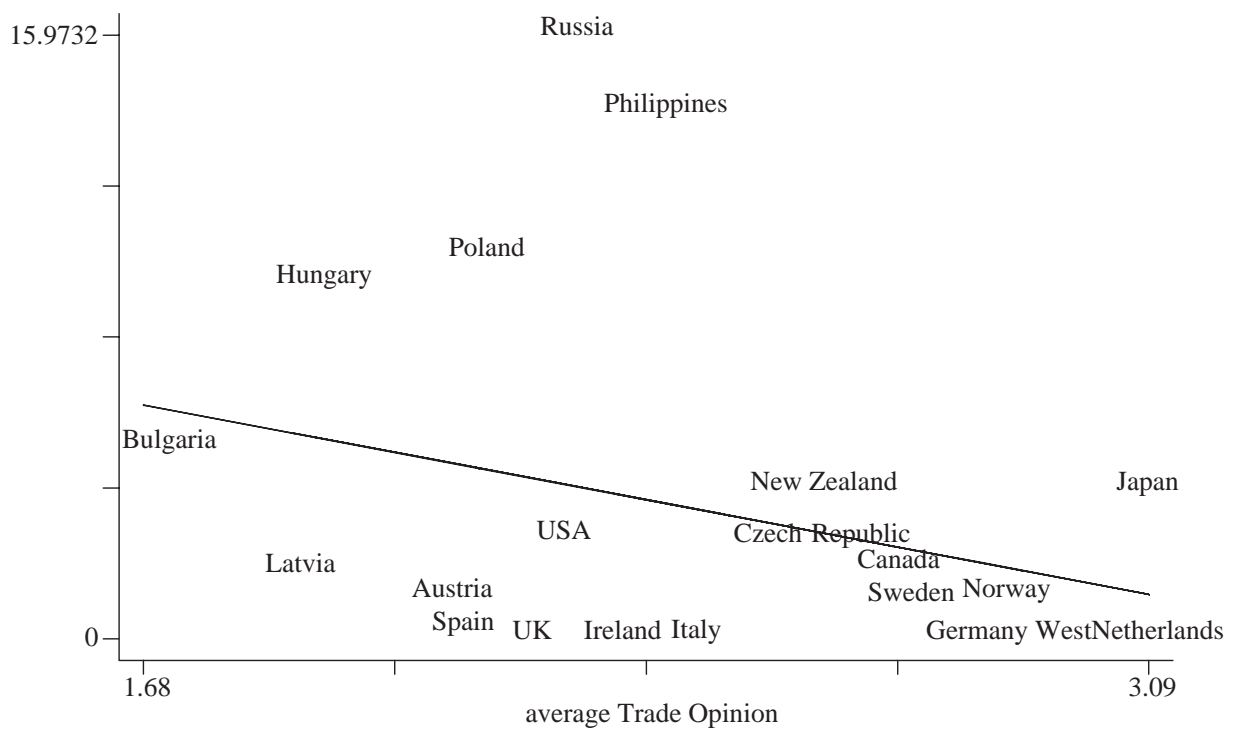

Fig. 1. Relationship between trade opinion and average trade duties (ISSP data set).

of Trade Opinion accounts for no more than 8 percent of the cross-country variation in tariffs.

As mentioned in the introduction, we use the third wave of the WVS data set (Inglehart, 1997), carried out in 1995-1997, to complement our findings based on the ISSP data set. While the WVS contains information on trade attitudes for more countries than the ISSP survey (47 countries, versus 23 ), its question on trade allows only a binary response: "Do you think it is better if: (1) Goods made in other countries can be imported and sold here if people want to buy them; or that: (2) There should be stricter limits on selling foreign goods here, to protect the jobs of people in this country; or: (9) Don't Know." In coding the responses, we followed the same procedures as with the ISSP survey. We constructed a binary variable, Pro-Trade Dummy (WVS), set equal to 1 if the individual answered (1), and equal to 0 if the individual answered (2) or (9). Missing values (no answer) were kept as missing values. ${ }^{10}$ Across countries that are covered in both the ISSP and WVS data sets, the simple correlation between average values of pro-trade attitudes is 0.72 (significant at the $95 \%$ level). ${ }^{11}$ One important shortcoming of the WVS is that it does not contain the information that would allow the matching of respondents to sectors of employment in the way that the ISSP data set does. This means that we cannot use the WVS for purposes of testing the implications of the specific-factors model.

\footnotetext{
${ }^{10} \mathrm{We}$ found that our analysis remains unaffected if we count "don't knows" as missing values instead.

${ }^{11}$ See Tables 2 and 3 for summary statistics of Pro-Trade Dummy (WVS) and for a comparison of the two data sets in terms of trade attitudes.
} 
Table 2

Summary data on individual attitudes towards trade (WVS)

\begin{tabular}{|c|c|c|c|}
\hline Country & $\begin{array}{l}\text { Pro-Trade } \\
\text { Dummy (WVS) }\end{array}$ & Country & $\begin{array}{l}\text { Pro-Trade } \\
\text { Dummy (WVS) }\end{array}$ \\
\hline Uruguay & 0.0720 & S. Korea & 0.3483 \\
\hline Venezuela & 0.1209 & Bulgaria & 0.3517 \\
\hline Brazil & 0.1297 & Switzerland & 0.3639 \\
\hline Argentina & 0.1395 & Germany East & 0.3647 \\
\hline Mexico & 0.1523 & Macedonia & 0.3697 \\
\hline Peru & 0.1528 & Finland & 0.3850 \\
\hline India & 0.1667 & Sweden & 0.4143 \\
\hline Turkey & 0.1747 & Estonia & 0.4251 \\
\hline Bangladesh & 0.1856 & Taiwan & 0.4554 \\
\hline Pakistan & 0.1951 & Latvia & 0.4583 \\
\hline Puerto Rico & 0.2109 & Croatia & 0.4676 \\
\hline Chile & 0.2170 & Norway & 0.4685 \\
\hline Poland & 0.2350 & Bosnia & 0.4700 \\
\hline Australia & 0.2366 & Nigeria & 0.4745 \\
\hline China & 0.2414 & Serbia & 0.4922 \\
\hline Dominican Republic & 0.2566 & Armenia & 0.5075 \\
\hline Spain & 0.2601 & Ukraine & 0.5240 \\
\hline USA & 0.2705 & Azerbaijan & 0.5280 \\
\hline Philippines & 0.2833 & Belarus & 0.5378 \\
\hline Lithuania & 0.2864 & Germany West & 0.5428 \\
\hline Slovenia & 0.2982 & Georgia & 0.5547 \\
\hline Russia & 0.3034 & Montenegro & 0.5708 \\
\hline Moldova & 0.3130 & Japan & 0.7170 \\
\hline S. Africa & 0.3431 & & \\
\hline Mean & 0.3490 & & \\
\hline Standard deviation & 0.4766 & & \\
\hline
\end{tabular}

Notes: Trade Opinion (WVS) gives responses to the following question: "Do you think it is better if: 1. Goods made in other countries can be imported and sold here if people want to buy them; or that: 2 . There should be stricter limits on selling foreign goods here, to protect the jobs of people in this country; or: 9. Don't Know." Pro-Trade Dummy (WVS) is coded as follows: Pro-Trade Dummy (WVS) $=1$ if Trade Opinion $($ WVS $)=1 ; 0$ if Trade Opinion $($ WVS $)=2$ or 9.

In most of our tests, we shall use Pro-Trade Dummy from the ISSP data set and Pro-Trade Dummy ( $W V S$ ) from the WVS as our dependent variables and estimate a series of probit models. We have checked the robustness of our results to alternative econometric models, estimating ordered logit specifications as well as OLS regressions with Trade Opinion as the dependent variable. We find very few substantive differences so we shall not present the results from these different specifications. ${ }^{12}$ When we present probit results, we report the marginal effect of each variable, i.e. the estimated change in the probability of being pro-trade ("disagree" and "disagree strongly" with trade restrictions) given a marginal increase in the value of the relevant regressor,

\footnotetext{
${ }^{12}$ See the working paper version (NBER Working Paper 8461) for ordered-logit results.
} 
Table 3

Comparison between ISSP and WVS data sets

\begin{tabular}{lll}
\hline Country & $\begin{array}{l}\text { Pro-Trade Dummy } \\
\text { (WVS) }\end{array}$ & $\begin{array}{l}\text { Pro-Trade Dummy } \\
\text { (ISSP) }\end{array}$ \\
\hline Poland & 0.2350 & 0.1439 \\
Spain & 0.2601 & 0.1024 \\
USA & 0.2705 & 0.1331 \\
Philippines & 0.2833 & 0.1600 \\
Slovenia & 0.2982 & 0.2442 \\
Russia & 0.3034 & 0.2183 \\
Bulgaria & 0.3517 & 0.0778 \\
Germany East & 0.3647 & 0.2206 \\
Sweden & 0.4143 & 0.2392 \\
Latvia & 0.4583 & 0.1312 \\
Norway & 0.4685 & 0.2770 \\
Germany West & 0.5428 & 0.3635 \\
Japan & 0.7170 & 0.3400 \\
\hline
\end{tabular}

Notes: In both data sets, Pro-Trade Dummy is set equal to 1 if an individual is in favor of imports, 0 if he is not in favor of imports. The correlation coefficient between the country average values of Pro-Trade Dummy in the two data sets is 0.7226 , significant at the $5 \%$ level (only countries for which data is available in both data sets were considered).

holding all other regressors at their mean value. These marginal effects represent the estimated impact that each regressor has on the probability that an "average" individual will be pro-trade. ${ }^{13}$

\section{A first pass: The naïve demographic model}

As a first pass through the data, we ignore economic theory and present some estimates that relate trade attitudes to a list of standard demographic characteristics. We use information from ISSP questions regarding age, gender, citizenship, years of education, real income, area of residence (rural vs. urban), subjective social class, trade union membership, and political party affiliation. ${ }^{14}$ The results are shown in the first two columns of Table 4 . The WVS data yield very similar results, which we do not present to save space. ${ }^{15}$

We find evidence of a strong gender effect on trade attitudes, which survives virtually all specifications we have tried. Column (1) in Table 4 shows that being male increases the probability of replying either "disagree" or "disagree strongly" with trade restrictions by 7.7 percentage points (significant at the $1 \%$ level). This is quite a

\footnotetext{
${ }^{13}$ As is mentioned above, in each specification we include a full set of country dummy variables that capture unobserved additive country-specific effects. We also cluster standard errors by country, to account for correlation across individuals within the same country.

${ }^{14}$ See definitions of variables at the end of Table 4.

${ }^{15}$ Some control variables are defined differently in regressions using the WVS due to differences in the questions posed: country of birth (in WVS) instead of citizenship (in ISSP), highest education level attained (in WVS) instead of years of education (in ISSP), town size (in WVS) instead of rural vs. urban (in ISSP).
} 
Table 4

Factor endowments model (ISSP data set)

\begin{tabular}{|c|c|c|c|c|c|c|c|c|c|}
\hline Probit with country dummy variables & 1 & 2 & 3 & 4 & 5 & 6 & 7 & 8 & 9 \\
\hline Dependent variable & \multicolumn{9}{|c|}{ Pro-trade dummy } \\
\hline Age & $\begin{array}{c}-0.0008 \\
0.0004+\end{array}$ & $\begin{array}{r}-0.0007 \\
0.0006\end{array}$ & $\begin{array}{c}-0.0008 \\
0.0004+\end{array}$ & $\begin{array}{c}-0.0008 \\
0.0005+\end{array}$ & $\begin{array}{r}-0.0005 \\
0.0004\end{array}$ & $\begin{array}{c}-0.0010 \\
0.0004^{*}\end{array}$ & $\begin{array}{r}-0.0010 \\
0.0004^{*}\end{array}$ & $\begin{array}{r}-0.0007 \\
0.0005\end{array}$ & $\begin{array}{c}-0.0008 \\
0.0004+\end{array}$ \\
\hline Male & $\begin{array}{l}0.0766 \\
0.0087 * *\end{array}$ & $\begin{array}{l}0.0688 \\
0.0151^{* *}\end{array}$ & $\begin{array}{l}0.0760 \\
0.0092 * *\end{array}$ & $\begin{array}{l}0.0801 \\
0.0089 * *\end{array}$ & $\begin{array}{l}0.0950 \\
0.0077^{* *}\end{array}$ & $\begin{array}{l}0.0719 \\
0.0089^{* *}\end{array}$ & $\begin{array}{l}0.0719 \\
0.0089 * *\end{array}$ & $\begin{array}{l}0.0730 \\
0.0098 * *\end{array}$ & $\begin{array}{l}0.0734 \\
0.0093 * *\end{array}$ \\
\hline Citizen & $\begin{array}{c}-0.0751 \\
0.0332 *\end{array}$ & $\begin{array}{l}-0.2003 \\
0.0423^{* *}\end{array}$ & $\begin{array}{c}-0.0743 \\
0.0328^{*}\end{array}$ & $\begin{array}{c}-0.0769 \\
0.0337^{*}\end{array}$ & $\begin{array}{l}-0.1146 \\
0.0381 * *\end{array}$ & $\begin{array}{c}-0.0819 \\
0.0323^{*}\end{array}$ & $\begin{array}{c}-0.0819 \\
0.0322^{*}\end{array}$ & $\begin{array}{c}-0.0652 \\
0.0329^{*}\end{array}$ & $\begin{array}{c}-0.0662 \\
0.0325^{*}\end{array}$ \\
\hline Education $*$ gdp & & & $\begin{array}{l}0.0142 \\
0.0032 * *\end{array}$ & $\begin{array}{l}0.0102 \\
0.0021 * *\end{array}$ & $\begin{array}{l}0.0135 \\
0.0054^{*}\end{array}$ & $\begin{array}{l}0.0121 \\
0.0032^{* *}\end{array}$ & $\begin{array}{l}0.0120 \\
0.0035^{* *}\end{array}$ & $\begin{array}{l}0.0146 \\
0.0039^{* *}\end{array}$ & $\begin{array}{l}0.0140 \\
0.0033 * *\end{array}$ \\
\hline Log of real income & & $\begin{array}{l}0.0380 \\
0.0115^{* *}\end{array}$ & & & & $\begin{array}{l}0.0542 \\
0.0070^{* *}\end{array}$ & $\begin{array}{l}0.0478 \\
0.1305\end{array}$ & & \\
\hline Log of real income $*$ gdp & & & & & & & $\begin{array}{l}0.0007 \\
0.0140\end{array}$ & & \\
\hline Education $*$ import duties & & & & & & & & $\begin{array}{l}0.0002 \\
0.0005\end{array}$ & \\
\hline Education $*$ (imports/gdp) & & & & & & & & & $\begin{array}{l}0.0000 \\
0.0001\end{array}$ \\
\hline Rural & & $\begin{array}{r}-0.0095 \\
0.0083\end{array}$ & & & & & & & \\
\hline Upper social class & & $\begin{array}{l}0.0314 \\
0.0059^{* *}\end{array}$ & & & & & & & \\
\hline Trade union member & & $\begin{array}{r}-0.0110 \\
0.0207\end{array}$ & & & & & & & \\
\hline Political affiliation with the right & & $\begin{array}{l}0.0375 \\
0.0122 * *\end{array}$ & & & & & & & \\
\hline Number obs & 24025 & 4834 & 24025 & 22874 & 18719 & 16611 & 16611 & 21692 & 23023 \\
\hline Pseudo $R^{2}$ & 0.08 & 0.09 & 0.08 & 0.08 & 0.09 & 0.09 & 0.09 & 0.08 & 0.08 \\
\hline
\end{tabular}

Notes: The table contains the estimated marginal effect on the probability of being pro-trade, given an increase in the value of the relevant regressor, holding all other regressors at their mean value. The standard errors of the marginal effect of each relevant regressor - adjusted for clustering on country - are presented under each marginal effect. + significant at $10 \% ; *$ significant at $5 \%$;* significant at $1 \%$. In regression (4) we drop the Philippines. In regressions (5), we drop low-income countries (Poland, Bulgaria, Russia, Latvia and the Philippines). Pro-Trade Dummy is coded as follows: Pro-Trade Dummy $=1$ if Trade Opinion $=4$ or 5 ; 0 if Trade Opinion $=1,2,3,8$, or 9 . Education refers to years of education, with a maximum top-coding (introduced by us) of 20. gdp is the log of per capita GDP in 1995, PPP (current international dollars). Rural is coded as follows: $1=$ urban, 2 = suburbs/city-town, $3=$ rural. Log of real income is calculated using data in local currency on individual yearly income from the ISSP data set and purchasing power parity conversion factors from the WDI (World Bank). import duties are average import duties (as \% of imports) in 1990-1995. imports/gdp is the average imports-to-GDP ratio in 1990-1995. Upper social class is coded as follows: $1=$ lower, $2=$ working, $3=$ lower middle, $4=$ middle, $5=$ upper middle, $6=$ upper. Trade union member equals 1 if the individual is a member of a trade union, 0 if he is not. Political affiliation with the right is coded as follows: $1=$ far left, $2=$ centre left, $3=$ centre, $4=$ right, $5=$ far right. 
striking difference given that only $22 \%$ of the ISSP sample overall is pro-trade. This gender-based difference in trade attitudes provides us with an early glimpse into the important role played by values in shaping attitudes. ${ }^{16}$ Older individuals appear to be more protectionist, but the estimates are not always significant. ${ }^{17}$ Citizenship in the country is negatively associated with pro-trade sentiments, while political affiliation with the right has a positive and significant impact on pro-trade attitudes. ${ }^{18}$ Finally, self-evaluations of high social status (upper social class) have a positive effect on pro-trade attitudes, i.e. individuals who identify themselves as belonging to one of the upper classes are more likely to oppose protection.

Column (2) in Table 4 shows that an individual's real income is positively associated with pro-trade attitudes, even after controlling for education and other sociodemographic attributes. Given that a full set of country dummy variables is included in the specification, this marginal effect captures the impact of the variation of individual income within each country, i.e. the effect of relative income. Thus trade is generally perceived to be a good thing for individuals at the high end of a country's income distribution, and a bad thing for those at the bottom. This result survives various robustness checks, including embedding the income variable in the economic frameworks we discuss below. We are not aware of any simple economic theory that would explain this finding, and we leave the development of such a theory to further research. Whatever the underlying story, one interesting implication of the relationship between relative income and pro-trade attitudes is worth noting. Consider a political-economy model in which trade policies are determined by the preferences of the median voter (as in Mayer, 1984). In countries with greater income inequality the median voter will normally have a lower relative income than in countries with greater equality. Consequently, greater inequality will be associated with higher levels of trade protection across countries.

When we modify the naïve demographics specification below, we shall drop some of the socio-demographic variables (area of residence, subjective social class, political party affiliation and trade union membership) because we would be losing too many observations to missing values otherwise. We shall keep age, gender, citizenship and education as controls in all specifications.

\section{Economic determinants of individual attitudes: The factor-endowments model}

Moving towards free trade, a country that is well endowed with skilled labor will experience an increase in the relative price of skill-intensive goods and correspond-

\footnotetext{
${ }^{16} \mathrm{An}$ alternative hypothesis is that gender differences arise from the significantly lower levels of labor-market participation of women or from differences in the labor-market positions of women relative to men. We do not find evidence of such effects when we control for whether an individual is in the labor market or not, or when we control for comparative-advantage (comparative-disadvantage) status of the individual's sector of employment.

${ }^{17} \mathrm{We}$ do not find evidence of non-linear effects of age on pro-trade attitudes.

18 Trade union membership is associated with protectionist attitudes, but the effect is not significant in the simple probit specification.
} 
ingly specialize in the production of those goods. According to the Stolper-Samuelson theorem, skilled workers in all sectors of the economy will gain and unskilled workers will lose. A key assumption of the factor-endowments model - of which the StolperSamuelson theorem is an implication - is that factors of production can move costlessly across economic sectors. This is an extreme assumption. However, as long as the time horizon individuals use to evaluate trade policy is a long-run one - in which rates of return to factors are equalized across sectors - their attitudes over trade policy will be informed by the underlying logic of the Stolper-Samuelson theorem. In this section, we test this idea.

We first focus on the analysis of the ISSP data set. We use as our theoretical backdrop a world in which skilled and unskilled labor are the only relevant factors of production. We do not have information on capital ownership, so we shunt it aside by assuming that it plays an insignificant role in shaping comparative advantage, perhaps because it is internationally mobile. Our measure of skill is years of education (education), which we have already used above.

According to the factor-endowments model, an individual's trade policy attitudes will depend both on his skill level and on his country's relative factor endowment. A skilled individual will be pro-trade in an economy that is well endowed with skilled labor, but anti-trade in an economy that is well endowed with low-skill labor. So we need information also on an economy's relative abundance in skilled labor. As a proxy for relative factor endowments, we shall use per-capita GDP (in 1995, PPP-adjusted). Table 14 in Appendix B presents per capita GDP values for the countries included in the two data sets. It is reasonable to suppose that countries with higher values of GDP per capita are also better endowed with skilled labor. ${ }^{19}$

Before we present regression results, it is instructive to examine whether the estimated effect of education varies systematically across countries in the manner predicted by the Stolper-Samuelson theorem. So we first ran a series of probit regressions on individual countries, with Pro-Trade Dummy as the dependent variable. In each case, we regressed Pro-Trade Dummy on education (along with age and male). In Fig. 2a, we plot the estimated marginal effects we obtained on education alongside each country's per-capita GDP. The result is striking: there is a very strong and tight relationship between a country's per-capita GDP and the magnitude of the corresponding estimated marginal effect of education (the coefficient of per capita GDP is 1.53 percentage points per US $\$ 10,000$, robust $t$-statistic $=4.97$, significant at $1 \%$ level). The richer a country, the more positive is the impact of a marginal increase of education on the probability of pro-trade attitudes. The Philippines lies at the low end of the spectrum, and is without question the country with the lowest skill endowment in the ISSP sample. The marginal effect of education we obtained for the Philippines is not only the smallest among all countries in the ISSP data set, it is actually negative (and

\footnotetext{
${ }^{19}$ We could have also used the Barro and Lee $(1996,2000)$ data sets, but these suffer from some clear defects where the countries in our sample are concerned. For example, when we construct a measure of relative human capital endowment (high-skilled vs low-skilled labor) by considering no schooling and primary schooling attainment in the low-skilled labor measure and secondary schooling and higher schooling attainment in the high-skilled labor measure, we obtain that West Germany and Spain rank lower than the Philippines in 1990.
} 


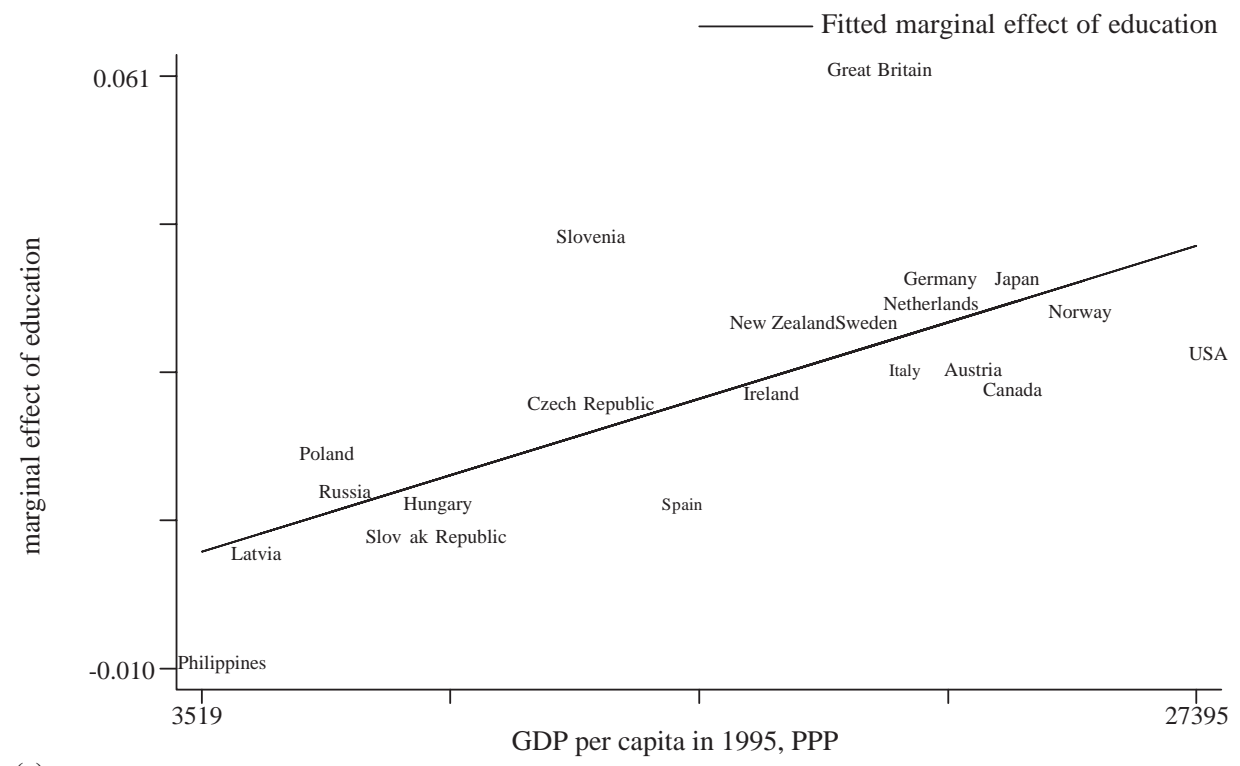

(a)

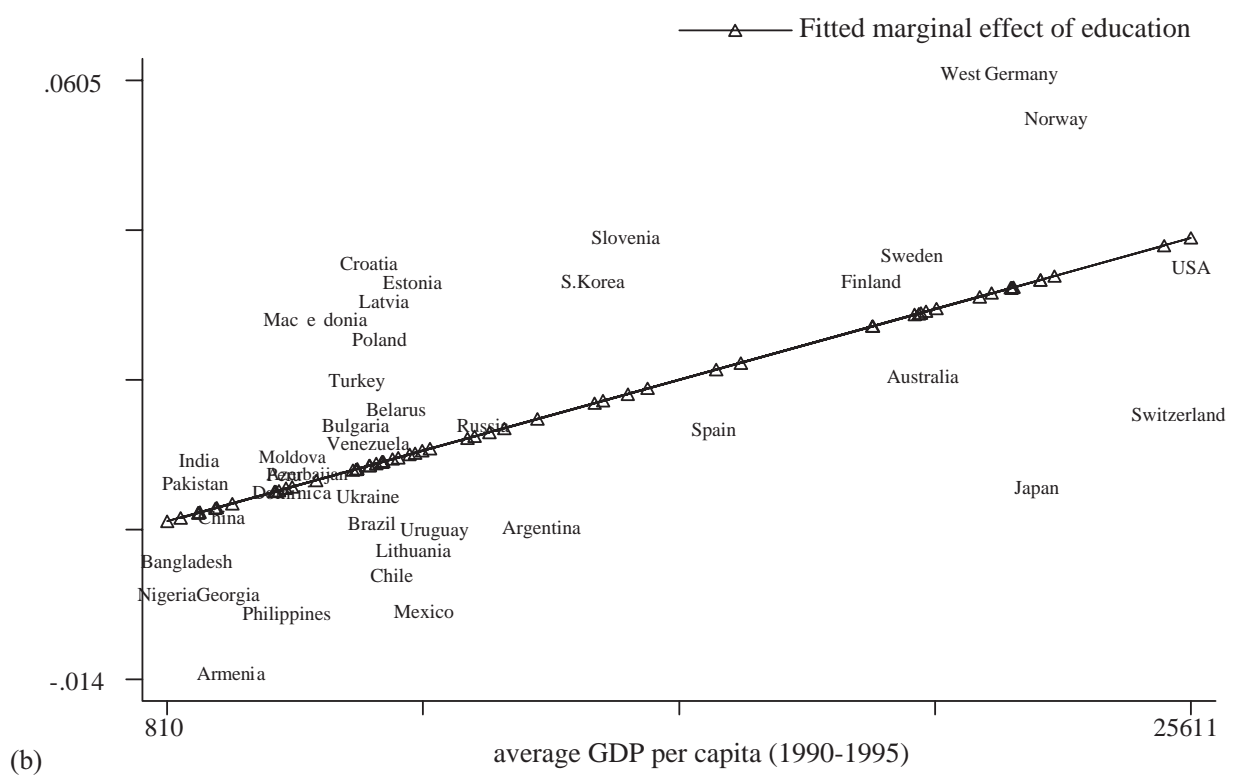

Fig. 2. Relationship between per-capita GDP and the estimated marginal effect of: (a) education on pro-trade attitudes (ISSP data set) and, (b) occupational skill on pro-trade attitudes (WVS data set).

statistically significant at the $1 \%$ level). Greater education is associated with more protectionist views in the Philippines - the only such case in the ISSP sample. These findings are quite in line with the Stolper-Samuelson theorem. 
In columns (3)-(9) of Table 4 we show pooled regressions, with a full set of country dummies, where we take into account the cross-country heterogeneity with respect to the effect of education. In regression (3), we interact education with log per-capita GDP, education $* g d p$, and enter the main effect of education separately. ${ }^{20}$ The previous exercise on individual countries suggests that the impact of education should depend on the level of per-capita GDP; that is, we should get a negative coefficient on education but a positive coefficient on the interaction term education $* g d p$. This is exactly what we get. ${ }^{21}$ Both terms are highly significant. Columns (4) and (5) confirm that the pattern continues to hold when we drop the Philippines and the other lower-income countries from the sample. ${ }^{22}$ This is important evidence, suggesting that the non-linearity in education is present for the entire range of countries; it is not an artifact driven by either the Philippines or a small number of low-income countries. Column (6) confirms that the result is robust to controlling for an individual's real income. Finally, in regression (7), we introduce an additional interaction term between individual income and per-capita GDP, $\log$ of real income $* g d p$, to confirm that what we are capturing is a non-linearity in the impact of education, and not with respect to income/earnings.

We also take into consideration the possibility that different levels of trade policy may affect individuals within a country not uniformly. In particular, international differences in trade openness may impact the interaction coefficient of individual skill and country factor-endowments. We are worried about the possibility that richer countries are more open to trade and that the distributive implications are therefore more evident there. To guard against this, we interact education with both a country's average import-tariff level and its import/GDP ratio (columns (8) and (9), Table 4). However, we find that the coefficients on these interaction terms, which are insignificant, are not supportive of this possibility. And more important, in neither case are the findings on the Stolper-Samuelson effect altered. ${ }^{23}$

Since the WVS covers more countries, including many more low-income countries, it is important to check whether these results carry over to the WVS data set. This is done in Table 5. The WVS allows us to use four different measures of skill: the highest education level attained by the individual (education), the age at which the individual finished school (education age), the skill of the individual according to an occupation-based classification (individual skill), and the skill of the chief wage earner in the household according to the same occupation-based classification ( $c w e$ skill). Depending on the measure of skill used, the number of countries included is either 37 or 40, which is a significant improvement over 23. As before, we use the log of per capita GDP (in 1995, PPP-adjusted) to measure each country's endowment of skilled labor.

Table 5 reveals the same non-linear pattern with respect to the impact of skill on pro-trade attitudes that we uncovered with the ISSP data set. Regardless of the

\footnotetext{
${ }^{20}$ Notice that the main effect of per capita GDP is captured by the country dummy variables.

${ }^{21}$ O'Rourke and Sinnott (2001) have independently replicated this result, even though their measure of skill is different from ours. These authors use an occupational measure, in contrast to our educational measure.

22 The countries dropped are Poland, Bulgaria, Russia, Latvia and the Philippines.

${ }^{23}$ Regressions (7) and (8) in Table 5 show parallel results using the WVS data: again, the findings of the Stolper-Samuelson effect are not altered.
} 
Table 5

Factor endowments model (WVS data set)

\begin{tabular}{|c|c|c|c|c|c|c|c|c|}
\hline Probit with country dummies & 1 & 2 & 3 & 4 & 5 & 6 & 7 & 8 \\
\hline Dependent variable & Pro-Trade D & yy (WVS) & & & & & & \\
\hline Age & $\begin{array}{l}-0.003 \\
0.0001 * *\end{array}$ & $\begin{array}{c}-0.0026 \\
0.0002 * *\end{array}$ & $\begin{array}{c}-0.0039 \\
0.0002 * *\end{array}$ & $\begin{array}{c}-0.0034 \\
0.0002 * *\end{array}$ & $\begin{array}{l}-0.004 \\
0.0002 * *\end{array}$ & $\begin{array}{l}-0.0034 \\
0.0002 * *\end{array}$ & $\begin{array}{l}-0.0025 \\
0.0002 * *\end{array}$ & $\begin{array}{l}-0.003 \\
0.0001 * *\end{array}$ \\
\hline Male & $\begin{array}{l}0.0365 \\
0.0043 * *\end{array}$ & $\begin{array}{l}0.0721 \\
0.0078^{* *}\end{array}$ & $\begin{array}{l}0.0385 \\
0.0046^{* *}\end{array}$ & $\begin{array}{l}0.0344 \\
0.0047 * *\end{array}$ & $\begin{array}{l}0.044 \\
0.0050^{* *}\end{array}$ & $\begin{array}{l}0.0239 \\
0.0072 * *\end{array}$ & $\begin{array}{l}0.0464 \\
0.0049 * *\end{array}$ & $\begin{array}{l}0.037 \\
0.0043 * *\end{array}$ \\
\hline Country of birth & $\begin{array}{c}-0.0463 \\
0.0094^{* *}\end{array}$ & $\begin{array}{l}-0.1037 \\
0.0159 * *\end{array}$ & $\begin{array}{c}-0.0469 \\
0.0099^{* *}\end{array}$ & $\begin{array}{c}-0.0419 \\
0.0101 * *\end{array}$ & $\begin{array}{c}-0.0535 \\
0.0103^{* *}\end{array}$ & $\begin{array}{c}-0.0294 \\
0.0152+\end{array}$ & $\begin{array}{l}-0.0767 \\
0.0116^{* *}\end{array}$ & $\begin{array}{c}-0.0418 \\
0.0095 * *\end{array}$ \\
\hline Education (educational attainment) & $\begin{array}{c}-0.1004 \\
0.0090^{* *}\end{array}$ & $\begin{array}{c}-0.1399 \\
0.0248^{* *}\end{array}$ & & & & & $\begin{array}{c}-0.1184 \\
0.0166^{* *}\end{array}$ & $\begin{array}{l}-0.106 \\
0.0096 * *\end{array}$ \\
\hline Education $*$ gdp & $\begin{array}{l}0.014 \\
0.0011^{* *}\end{array}$ & $\begin{array}{l}0.0185 \\
0.0026^{* *}\end{array}$ & & & & & $\begin{array}{l}0.0156 \\
0.0018^{* *}\end{array}$ & $\begin{array}{l}0.0143 \\
0.0011^{* *}\end{array}$ \\
\hline $\begin{array}{l}\text { Education age } \\
\text { (age at which education completed) } \\
\text { Education age } * \text { gdp }\end{array}$ & & & $\begin{array}{l}-0.0232 \\
0.0043^{* *} \\
0.0031 \\
0.0005^{* *}\end{array}$ & $\begin{array}{l}-0.057 \\
0.0054^{* *} \\
0.0077 \\
0.0006^{* *}\end{array}$ & & & & \\
\hline $\begin{array}{l}\text { Individual skill } \\
\text { (occupation-based individual skill) } \\
\text { Individual skill } * \text { gdp }\end{array}$ & & & & & $\begin{array}{c}-0.0831 \\
0.0086^{* *} \\
0.0115 \\
0.0010^{* *}\end{array}$ & & & \\
\hline Education $*$ import duties & & & & & & & $\begin{array}{l}0.0006 \\
0.0002 * *\end{array}$ & \\
\hline Education $*($ imports/GDP) & & & & & & & & $\begin{array}{l}0.0001 \\
0.0001+\end{array}$ \\
\hline Number obs & 50771 & 15166 & 46143 & 44495 & 40068 & 22962 & 35413 & 49789 \\
\hline Pseudo $R^{2}$ & 0.1 & 0.07 & 0.1 & 0.1 & 0.1 & 0.11 & 0.09 & 0.1 \\
\hline
\end{tabular}

Notes: The table contains the estimated marginal effect on the probability of being pro-trade, given an increase in the value of the relevant regressor, holding all other regressors at their mean value. The standard errors of the marginal effect of each relevant regressor - adjusted for clustering on country - are presented under each marginal effect. + significant at $10 \%$; ** significant at $1 \%$. Education (the highest education level attained by the individual) is coded as follows: $1=$ no formal education; $2=$ incomplete primary school; $3=$ complete primary school; $4=$ incomplete secondary school (technical/vocational type); $5=$ complete secondary school (technical/vocational type); $6=$ incomplete secondary (university/preparatory type); $7=$ complete secondary (university/preparatory type); $8=$ some university-level education, without degree; $9=$ university level education, with degree. Education age is the age at which the individual finished school. Individual skill is coded as follows: $1=$ agricultural worker; $2=$ farmer (own farm); $3=$ unskilled manual worker; $4=$ semi-skilled manual worker; $5=$ skilled manual worker; $6=$ foreman and supervisor; $7=$ non manual-office worker (non-supervisory); $8=$ supervisory-office worker; $9=$ professional worker (lawyer, accountant, teacher, etc.); $10=$ employer/manager of establishment with less than 10 employees; $11=$ employer/manager of establishment with 10 or more employees. cwe (chief wage earner in the household) skill is coded in the same way as individual skill. Regression (2) is the same as (1) but it only considers observations from the countries in common between the ISSP and the WVS data sets (see Table 3). Regression (4) is the same as regression (3) but it excludes individuals who finished school when they were more than 30 years old. import duties are average import duties (as \% of imports) in 1990-1995. imports/gdp is the average imports-to-GDP ratio in 1990-1995. 
measure of skill used, the estimated marginal effect of skill is negative (and significant), while the estimated marginal effect of skill interacted with per-capita GDP is positive (and also significant). As we did with the ISSP data, we also plot the estimated marginal effect of individual skill against a country's per-capita GDP. Fig. 2b shows the scatter plot for the occupation-based skill measure (the others are quite similar). The relationship has a distinctly positive slope: the associated regression slope has a robust $t$-statistic of 3.85. The poorest countries in the sample - Bangladesh, Nigeria, Armenia, Georgia - are those where more skill is associated with less pro-trade views. None of the richer countries exhibits this reversal.

Overall, these findings are strikingly supportive of the implications of the factorendowments model and of the Stolper-Samuelson theorem. Education and skill are very strongly correlated with support for free trade in countries that are well endowed with human capital. It is either weakly or negatively correlated with support for free trade in countries that are poorly endowed with human capital. No other theory that we are aware of can explain this pattern. In particular, these findings are hard to square with the hypothesis that better educated people prefer more trade simply because they have a better understanding of comparative advantage or because they get more out of contact with foreign countries/products.

\section{Economic determinants of individual attitudes: The specific-factors model}

If individuals are on average immobile across industries, attitudes towards trade should be determined by their sector of employment, rather than their factor type. Respondents working in sectors where the home economy has a comparative advantage should be pro-trade; respondents employed in comparative-disadvantage sectors should be protectionist; and individuals in non-traded sectors on balance indifferent or pro-trade. This is the central insight of the specific-factors model.

In taking this insight to our data, we face an immediate problem. The ISSP survey contains no direct question about sector of employment. But it does provide very detailed information on occupation (based on the 4-digit International Standard Classification of Occupations [ISCO] or national classifications). We do our best to infer sector of employment from this data on occupation. Since our goal is to establish a correspondence between these sectors and international trade data, we recode the occupation variables according to the industry classification used in the World Trade Analyzer (WTA) data set. In particular, we end up reorganizing the data on the basis of a breakdown into 34 manufacturing industries (plus one - non-manufacturing) as defined by the U.S. Bureau of Economic Analysis (BEA). Since the occupation codes used in the ISSP data set are not always detailed enough to be matched with any single BEA code, we create in addition new codes as combinations of the original codes. This results in a total of 54 (partly overlapping) sectors. The details of our procedures and the sectoral breakdown we use are discussed in Appendix A. In some cases, the mapping is straightforward, as many occupational codes (e.g., "dairy and livestock producers", "chemical-processing-plant operators", or "aircraft engine mechanics and fitters") are directly indicative of sectors. In other cases, it is impossible to assign an 
individual to a specific sector, and this results in either a less precise recoding or in missing values.

We determine a sector's revealed comparative advantage (or comparative disadvantage) by looking at the sign of adjusted net imports in that sector (averaged over the years 1990-1995). The adjustment is meant to "correct" for the existence of overall trade imbalances. Hence, we define an adjustment factor, $\lambda$, as follows:

$$
\lambda=\frac{\sum_{i}\left(M_{i}-X_{i}\right)}{\sum_{i} M_{i}} .
$$

The indicator $\lambda$ is positive for countries that have a trade deficit and negative for countries with a trade surplus. In particular, $\lambda$ tells us by what fraction imports in each sector would have to be reduced in order to balance the trade account. Our measure of adjusted net imports in each sector is the difference between $(1-\lambda) M_{i}$ and $X_{i}$. We then define the two sector-specific variables, $C A_{i k}$ (comparative-advantage sector) and $C D_{i k}$ (comparative-disadvantage sector) for each sector $i$ in country $k$ as follows:

$$
\begin{aligned}
& C A_{i k}= \begin{cases}1, & \text { if } M_{i k}-X_{i k}-\lambda M_{i k}<0, \text { for } \operatorname{sector}_{i k}=1, \ldots, 54, \\
0, & \text { if } M_{i k}-X_{i k}-\lambda M_{i k}>0, \text { for } \operatorname{sector}_{i k}=1, \ldots, 54 \text { or if non-tradable sector, }\end{cases} \\
& C D_{i k}= \begin{cases}1, & \text { if } M_{i k}-X_{i k}-\lambda M_{i k}>0, \text { for } \operatorname{sector}_{i k}=1, \ldots, 54, \\
0, & \text { if } M_{i k}-X_{i k}-\lambda M_{i k}<0, \text { for } \operatorname{sector}_{i k}=1, \ldots, 54 \text { or if non-tradable sector. }\end{cases}
\end{aligned}
$$

A sector is defined as a comparative-advantage sector if its adjusted net imports are less than zero and as a comparative-disadvantage sector if its adjusted net imports are greater than zero. Each individual is therefore assigned to one of three types of sectors: (a) a comparative-advantage sector; (b) a comparative-disadvantage sector; or (c) a non-tradable sector. ${ }^{24}$

The sector classification based on the occupation variables delivers a fairly good measure of the comparative-advantage (comparative-disadvantage) status of each individual. We use external data from another ISSP data set, Social Inequality II (1992), which contains information on both individuals' sector of employment and occupation for the United States, Germany, and Austria. For approximately $85 \%$ of individuals in these three countries for whom both sector and occupation data is available, our reclassification on the occupation data produces the same information on comparative-advantage and comparative-disadvantage status as if direct data on sector had been used. ${ }^{25}$

The first regression in Table 6 shows the results of our test of the sector-specific model. An individual in a comparative-disadvantage sector is significantly less likely to be pro-trade (by 2.5 percentage points), compared to an individual in a non-traded sector. This is highly supportive of the specific-factors model. Perhaps surprisingly, an individual in a comparative-advantage industry is not more likely to be pro-trade than

\footnotetext{
24 This is true unless the individual has not reported his occupation or there is no data on imports and exports for his sector of employment, in which case the individual is assigned a missing value.

${ }^{25}$ A separate appendix describing this analysis along with the analysis of attenuation bias arising from misclassification (see Card, 1996) is available upon request. We thank Jörn-Steffen Pischke and an anonymous referee for suggestions that prompted these analyses.
} 
Table 6

Sector specific model (ISSP data set)

Probit with country dummy variables

\begin{tabular}{lllll}
\hline 1 & 2 & 3 & 4 & 5
\end{tabular}

Dependent variable

Pro-Trade Dummy

\begin{tabular}{|c|c|c|c|c|c|}
\hline \multirow[t]{2}{*}{ Age } & -0.0004 & -0.0004 & -0.0005 & -0.0005 & -0.0004 \\
\hline & 0.0004 & 0.0004 & 0.0004 & 0.0004 & 0.0005 \\
\hline \multirow[t]{2}{*}{ Male } & 0.0802 & 0.0805 & 0.0811 & 0.0808 & 0.0846 \\
\hline & $0.0129 * *$ & $0.0125 * *$ & $0.0130 * *$ & $0.0128 * *$ & $0.0131 * *$ \\
\hline \multirow[t]{2}{*}{ Citizen } & -0.0695 & -0.0691 & -0.068 & -0.0678 & -0.0693 \\
\hline & $0.0390+$ & $0.0387+$ & $0.0396+$ & $0.0392+$ & $0.0413+$ \\
\hline \multirow[t]{2}{*}{ Education (years of education) } & 0.019 & 0.0189 & -0.1332 & -0.1303 & -0.124 \\
\hline & $0.0028 * *$ & $0.0030 * *$ & $0.0238 * *$ & $0.0254 * *$ & $0.0241 * *$ \\
\hline \multirow[t]{2}{*}{ Education $*$ gdp } & & & 0.016 & 0.0157 & 0.0154 \\
\hline & & & $0.0025 * *$ & $0.0027 * *$ & $0.0026 * *$ \\
\hline \multirow[t]{2}{*}{ CA sector } & -0.0133 & & -0.0207 & & 0.0115 \\
\hline & 0.0239 & & 0.0187 & & 0.0358 \\
\hline \multirow{2}{*}{$\mathrm{CD}$ sector } & -0.0252 & & -0.0204 & & -0.0168 \\
\hline & $0.0116^{*}$ & & $0.0122+$ & & 0.0311 \\
\hline \multirow[t]{2}{*}{ Exports } & & -271.602 & & -242.337 & \\
\hline & & 408.5989 & & 416.4975 & \\
\hline \multirow[t]{2}{*}{ Imports } & & $-1,807.68$ & & $-1,567.50$ & \\
\hline & & $721.0540 *$ & & $703.3980^{*}$ & \\
\hline \multirow[t]{2}{*}{ Education $*$ willingness to move } & & & & & -0.0336 \\
\hline & & & & & 0.0308 \\
\hline \multirow[t]{2}{*}{ Education $* \mathrm{gdp} *$ willingness to move } & & & & & 0.0027 \\
\hline & & & & & 0.003 \\
\hline \multirow[t]{2}{*}{ Willingness to move } & & & & & 0.126 \\
\hline & & & & & $0.0671+$ \\
\hline \multirow[t]{2}{*}{$\mathrm{CA} *$ willingness to move } & & & & & -0.0454 \\
\hline & & & & & 0.0574 \\
\hline \multirow[t]{2}{*}{$\mathrm{CD} *$ willingness to move } & & & & & 0.002 \\
\hline & & & & & 0.0449 \\
\hline Number of obs & 12432 & 12432 & 12432 & 12432 & 11473 \\
\hline Pseudo $R^{2}$ & 0.07 & 0.07 & 0.07 & 0.07 & 0.07 \\
\hline
\end{tabular}

Notes: The table contains the estimated marginal effect on the probability of being pro-trade, given an increase in the value of the relevant regressor, holding all other regressors at their mean value. The standard errors of the marginal effect of each relevant regressor - adjusted for clustering on country - are presented under each marginal effect. + significant at 10\%; * significant at 5\%; ** significant at 1\%. Pro-Trade Dummy is coded as follows: Pro-Trade Dummy $=1$ if Trade Opinion $=4$ or 5; 0 if Trade Opinion=1,2,3,8, or 9. gdp is the log of per capita GDP in 1995, PPP (current international dollars). Willingness to move, which varies between 0 and 1 , measures the stated willingness to move to another city/town, in order to improve work or living conditions. A sector is defined as a $C A$ (comparative-advantage) sector if its adjusted net imports are less than zero and as a $C D$ (comparative-disadvantage) sector if its adjusted net imports are greater than zero. Exports refers to the value of exports in the respondent's sector of employment, normalized by GDP. Imports refers to the value of imports in the respondent's sector of employment, normalized by GDP. 
an individual in a non-traded sector: the marginal effect of $C A$ sector is negative but not significant. ${ }^{26}$

The latter result can be rationalized by considering the original survey question, which is meant to elicit attitudes related to restrictions on imports only. In the presence of two-way (intra-industry) trade, myopic individuals may oppose import restrictions in their sectors, even when those sectors are large exporters on balance. Additionally, our sectoral classification and aggregation procedures may have resulted in the lumping together of comparative-advantage and comparative-disadvantage sectors. Whatever the reason, the bottom line that emerges from this regression is that the main cleavage in preference formation over trade lies not between the two tradable sectors but between tradables and non-tradables.

An alternative specification, which takes into account the presence of two-way trade, is shown in column (2). Now we enter separately the actual volumes of exports and imports (normalized by GDP) of the sector in which an individual is employed. The logic of the specific-factors model (augmented by the possibility of two-way trade) is that the estimated coefficient on imports should be negative. The estimated coefficient on exports should be positive to the extent that individuals fear retaliation from abroad or see through the Lerner symmetry theorem. We do indeed find the negative (and significant) effect on the imports term. The estimated coefficient on exports, however, is insignificant. We interpret this as mildly supportive of the specific-factors model.

In columns (3) and (4), we carry out a joint test of the factor-endowments and specific-factors models. Both models survive, though the significance level of the comparative-disadvantage variable drops to $10 \%$. We also compare the two competing models, in their linear specification, using a non-nested test, the $J$ test proposed by Davidson and MacKinnon (Greene, 1997, p. 365). First, we estimate the two models separately: we regress Trade Opinion on age, gender and citizenship plus, respectively, education and education $* g d p$ (for the factor-endowments model) and CA sector and $C D$ sector (for the specific-factors model). Next, we augment each of the two specifications with the fitted values from the other model. We find that the coefficients on the fitted values are significant in both cases (but only at the $10 \%$ level for the specific-factors fitted values). ${ }^{27}$ Thus, the results based on the non-nested test - in favor of the factor-endowments model and marginally in favor of the sector-specific model - are consistent with what we found in column (3), Table 6.

It is important to emphasize that our analysis of misclassification - due to the use of the occupation-based sector classification - suggests that the attenuation factors of the specific-factors coefficients are of a very small magnitude (approximately 0.5). This implies that the coefficients of $C A$ sector and $C D$ sector could be substantially underestimated.

\footnotetext{
${ }^{26}$ In the ordered logit results, using as a common benchmark individuals in non-traded sectors, respondents in comparative-disadvantage industries are on average less likely to be pro-trade than respondents in export-oriented sectors: the coefficients on $C A$ sector and $C D$ sector are significantly different at the $10 \%$ level.

${ }^{27}$ In particular, we find that $H_{0}$ : factor-endowments model should be rejected in favor of $H_{1}$ : sector-specific model at a $90 \%$ level of significance. When we reverse the roles of $H_{0}$ and $H_{1}$, we find that $H_{0}$ : sector-specific model should be rejected in favor of $H_{1}$ : factor-endowments model at a $99 \%$ level of significance.
} 
The horse-race analysis between the factor-endowments model and the specific-factors model gives us information regarding the time-horizon individuals use to assess trade policy, i.e. whether they are thinking about the long-run (as in the factor-endowments model) or the short-run (as in the specific-factors model) or both. The variation across individuals in terms of the relative importance of the two time frameworks is likely to depend on mobility. A plausible interpretation is that a certain fraction of individuals in our sample view themselves as intersectorally mobile over the time horizon that is relevant to them, and a certain fraction think of themselves as stuck in their present line of employment. The first group's trade attitudes would be in accordance with the factor-endowments model, while the second group's attitudes would be in accordance with both the specific-factors model and the factor-endowments model. ${ }^{28}$

The ISSP data set contains some questions on mobility. In particular, individuals are asked: "If you could improve your work or living conditions, how willing or unwilling would you be to move to another town or city?" Answers to the questions range from "very unwilling" (1) to "very willing" (5). The question relates to geographical mobility rather than inter-sectoral mobility, but may still be indicative of the latter. This gives us an opportunity to check whether willingness to move relates to trade attitudes in the manner consistent with our interpretation.

Our discussion suggests a specification of the form $E+(1-$ mobile $) * S$, where $E$ are the regressors that capture the factor-endowments model, and $S$ are the regressors reflecting the specific-factors model (we include the education main effect as part of the $E$ set). If we estimate a regression with all the main effects ( $E, S$ and mobile) and interactions ( $E *$ mobile and $S *$ mobile), we should find that the coefficient on $E * m o b i l e$ is not significant and that the coefficients on $S$ and $S *$ mobile are equal in absolute value and with opposite signs. According to this model, the coefficient on the main effect mobile should not be significant. However, we would not be surprised to find a positive coefficient, since high mobility allows more flexibility in terms of other side-effects of trade liberalization not analyzed in the paper. ${ }^{29}$ We test these restrictions in regression (5), Table 6 .

First, the sign on the comparative advantage variable ( $C A$ sector) now becomes positive, in line with the original expectations from the specific-factors model (but the marginal effect is insignificant). Second, individuals in comparative-advantage sectors are less pro-trade (but not significantly) if their willingness to move is high. Third, individuals in comparative-disadvantage sectors express less protectionist sentiments when their stated willingness to move is high, although the interaction term in this case is nowhere near significant. ${ }^{30}$ These results are all consistent with our interpretation,

\footnotetext{
${ }^{28}$ The implicit assumption is that the economy behaves as in the specific-factors model in the short-run (i.e., the average mobility rate is low in the short run) and as in the factor-endowments model in the long-run (i.e., the average mobility rate is high in the long run). A mobile individual is not concerned about the short run, because he can move from sector to sector, but he cares about the long run.

${ }^{29}$ For example, trade liberalization may affect the value of assets in a certain area.

${ }^{30}$ Notice that the marginal effects of $C A$ sector and $C A^{*}$ willingness to move, in absolute value, are not significantly different from each other. The same is true for the marginal effects of $C D$ sector and $C D^{*}$ willingness to move.
} 
but the insignificance of the estimates prevents us from reading too much support into them.

\section{The role of values, identity, and attachments}

We have drawn attention to the importance of non-economic determinants of trade attitudes in the introduction. Indeed, some of our most interesting results pertain to the role of values, identity, and attachments in shaping individual attitudes on trade policy. These attributes are particularly significant in explaining differences in average trade attitudes across countries. We consider three different specifications in Table 7.

First, we look at the impact of community and regional attachments (column (1)). We focus on answers to the following questions: "How close do you feel to respondent's neighborhood?" (neighborhood attachment); respondent's town/city?" (town attachment); respondent's county/region?" (county attachment); respondent's country?" (national pride (1)); respondent's continent?" (continent attachment). ${ }^{31}$ The results show a clear pattern. Individuals with strong attachments to their neighborhood, county/region, or nation tend to be less pro-trade. ${ }^{32}$ The second set of issues we look at relates directly to patriotism, nationalism, and chauvinism. In addition to national pride (1), we focus on the following questions: "How much do you agree or disagree with the following statements? I would rather be a citizen of respondent's country than of any other country in the world." (national pride (2)); Generally respondent's country is a better country than most other countries." (national pride (3)); respondent's country should follow its own interests, even if this leads to conflicts with other nations." (national pride (4)). ${ }^{33}$ On the one hand, national pride entails feelings of patriotism, i.e. genuine attachment to one's own country. On the other, national pride can be associated with feelings of nationalism - or, in its extreme form, chauvinism - i.e. sentiments of superiority of one's own country (Smith and Jarkko, 1998). We interpret answers to national pride (1) and (2) as reflecting both feelings of patriotism and nationalism. National pride (3) matches perfectly Smith and Jarkko's (1998) definition of nationalism as a feeling of superiority of one's own country. National pride (4) applies this nationalistic stand to a practical situation.

In a world where there are gains from trade at the national level, we would expect patriotism to be positively correlated with pro-trade attitudes. Regardless of distributional implications, individuals who care about the country as a whole should be in favor of free trade. On the other hand, patriotic individuals might lean towards protection if trade is viewed as a zero-sum game between nations or its social consequences are judged as adverse. The results in column (2) of Table 7 are more in line with the latter interpretation. There is a particularly strong negative relationship between

\footnotetext{
${ }^{31}$ The four possible answers to these questions range from "not close at all" (1) to "very close" (4).

${ }^{32}$ Such attachments tend to be particularly strong in countries like Japan and Spain, and weak in Britain and the U.S. (see Table 12 in Appendix B).

33 The five possible answers to these questions range from "disagree strongly" (1) to "agree strongly" (5).
} 
Table 7

Community/national attachment model (ISSP data set)

\begin{tabular}{|c|c|c|c|c|}
\hline \multirow[b]{3}{*}{ Dependent variable } & \multicolumn{4}{|c|}{ Probit with country dummy variables } \\
\hline & 1 & 2 & 3 & 4 \\
\hline & \multicolumn{4}{|c|}{ Pro-Trade Dummy } \\
\hline \multirow[t]{2}{*}{ Age } & -0.0003 & -0.0001 & -0.0007 & 0.0001 \\
\hline & 0.0005 & 0.0004 & 0.0005 & 0.0004 \\
\hline \multirow[t]{2}{*}{ Male } & 0.0805 & 0.0832 & 0.0785 & 0.088 \\
\hline & $0.0089 * *$ & $0.0097 * *$ & $0.0081 * *$ & $0.0089 * *$ \\
\hline \multirow[t]{2}{*}{ Citizen } & -0.0759 & -0.0582 & -0.0846 & -0.0704 \\
\hline & $0.0379 *$ & $0.0249 *$ & $0.0284 * *$ & $0.0237 * *$ \\
\hline \multirow[t]{2}{*}{ Education (years of education) } & 0.019 & 0.0157 & 0.0196 & 0.0143 \\
\hline & $0.0025^{* *}$ & $0.0024 * *$ & $0.0027 * *$ & $0.0025 * *$ \\
\hline \multirow[t]{2}{*}{ Neighborhood attachment } & -0.0174 & & & -0.0157 \\
\hline & $0.0052 * *$ & & & $0.0051 * *$ \\
\hline \multirow[t]{2}{*}{ Town attachment } & 0.0069 & & & 0.0091 \\
\hline & 0.0056 & & & 0.0062 \\
\hline \multirow[t]{2}{*}{ County attachment } & -0.0213 & & & -0.0167 \\
\hline & $0.0051 * *$ & & & $0.0043 * *$ \\
\hline \multirow[t]{2}{*}{ Continent attachment } & 0.0259 & & & 0.018 \\
\hline & $0.0081 * *$ & & & $0.0083^{*}$ \\
\hline \multirow[t]{2}{*}{ National pride (1) } & -0.0232 & 0.002 & & -0.0045 \\
\hline & $0.0089 * *$ & 0.0066 & & 0.0078 \\
\hline \multirow[t]{2}{*}{ National pride (2) } & & -0.0379 & & -0.0381 \\
\hline & & $0.0042 * *$ & & $0.0042 * *$ \\
\hline \multirow[t]{2}{*}{ National pride (3) } & & -0.0224 & & -0.0203 \\
\hline & & $0.0051 * *$ & & $0.0068 * *$ \\
\hline \multirow[t]{2}{*}{ National pride (4) } & & -0.0527 & & -0.0551 \\
\hline & & $0.0044 * *$ & & $0.0046 * *$ \\
\hline \multirow[t]{2}{*}{ Pride in democracy } & & & 0.0134 & 0.0183 \\
\hline & & & $0.0061 *$ & $0.0053 * *$ \\
\hline \multirow[t]{2}{*}{ Pride in political influence } & & & -0.0311 & -0.0172 \\
\hline & & & $0.0077 * *$ & $0.0091+$ \\
\hline \multirow[t]{2}{*}{ Economic pride } & & & 0.0023 & 0.0097 \\
\hline & & & 0.007 & 0.0072 \\
\hline \multirow[t]{2}{*}{ Pride in social security system } & & & 0.0004 & 0.0034 \\
\hline & & & 0.0072 & 0.0078 \\
\hline Number of obs & 18993 & 20472 & 19867 & 15091 \\
\hline Pseudo $R^{2}$ & 0.08 & 0.11 & 0.08 & 0.12 \\
\hline
\end{tabular}

Notes: The table contains the estimated marginal effect on the probability of being pro-trade, given an increase in the value of the relevant regressor, holding all other regressors at their mean value. The standard errors of the marginal effect of each relevant regressor - adjusted for clustering on country - are presented under each marginal effect. + significant at 10\%; * significant at 5\%; ** significant at 1\%. Pro-Trade Dummy is coded as follows: Pro-Trade Dummy $=1$ if Trade Opinion $=4$ or 5; 0 if Trade Opinion =1,2,3,8, or 9. See Appendix B, Tables 12 and 13 for definitions of neighborhood attachment, town attachment, county attachment, continent attachment, national pride (1) - (4), pride in democracy, pride in political influence, economic pride, and pride in social security system. 
national pride (2) and pro-trade views. This is significant in explaining the cross-country variation in trade attitudes, as national pride (2) varies greatly among countries. ${ }^{34}$

At the more explicitly nationalistic end of things, the results are as one would have expected. Feelings of superiority of one's own country presumably encourage thoughts of national isolationism, and abstention from political alliances and other international economic relations. Individuals who agree with the statement that their country "should follow its own interests, even if this leads to conflicts with other nations" (national pride (4)) are significantly less likely to be pro-trade. ${ }^{35}$ These individuals clearly perceive trade as a zero-sum game. ${ }^{36}$

Finally, we turn to pride in specific national achievements. We focus on the following questions: "How proud are you of respondent's country in each of the following? The way democracy works." (pride in democracy); Political influence in world." (pride in political influence); Economic achievements." (economic pride); Social security system." (pride in social security system). ${ }^{37}$ As shown in column (3) of Table 7, pride in a country's democracy is positively correlated with pro-trade attitudes. We take this to indicate that trade is less threatening to individuals who have confidence in their country's political institutions. On the other hand, pride in a country's political influence in the world (where the U.S. tops the list) is negatively associated with pro-trade attributes.

\section{Concluding remarks}

In Table 8 we present our preferred specification, based on the models we have considered so far. The main constraint in formulating a "summary" model is that missing values for specific questions result in a reduction in the sample size as more explanatory variables are added. The specification in Table 8 represents our compromise. It is meant to capture the essential insights of all the approaches we have used in explaining the formation of trade attitudes, with one exception: we have had to exclude regressors that relate to the specific-factors model, because the sample size would become unacceptably low otherwise. ${ }^{38}$

\footnotetext{
${ }^{34}$ The percentage of respondents that would "rather be citizen of own country than of any other country" varies from $91 \%$ in the U.S. to only $50 \%$ in the Netherlands (Table 12 in Appendix B).

${ }^{35}$ The percentage of respondents who agree with the proposition that their own country's interests should be followed even at the cost of conflict with others ranges from $73 \%$ in Bulgaria to $19 \%$ in Japan (Table 12 in Appendix B).

${ }^{36}$ Where similar questions exist in the WVS, the results are very similar to those reported in the text for the ISSP data set. We do not present these results with the WVS to save space.

${ }^{37}$ As might be expected, levels of pride are generally quite low in the former socialist economies: only $9 \%$ of respondents are proud of the economic achievements of their country in Hungary, compared to $83 \%$ in Germany and $82 \%$ in the U.S. (Table 13 ).

${ }^{38}$ We tested the robustness of our results to changes in the size of the sample (for example, we estimated various specifications in previous tables restricting the sample to observations without missing values for the regressors in our preferred specification $(n=9696))$. We don't find substantive differences relative to our previous results.
} 
Table 8

Preferred specification (ISSP data set)

\begin{tabular}{|c|c|c|}
\hline \multirow[b]{4}{*}{ Dependent variable } & \multicolumn{2}{|l|}{ OLS } \\
\hline & 1 & 2 \\
\hline & Without country DV & With country DV \\
\hline & \multicolumn{2}{|l|}{ Trade opinion } \\
\hline \multirow[t]{2}{*}{ Age } & -0.0022 & -0.0023 \\
\hline & 0.0014 & $0.0013+$ \\
\hline \multirow[t]{2}{*}{ Male } & 0.2603 & 0.2252 \\
\hline & $0.0320 * *$ & $0.0339 * *$ \\
\hline \multirow[t]{2}{*}{ Education (years of education) } & -0.1953 & -0.3798 \\
\hline & $0.0903^{*}$ & $0.0932 * *$ \\
\hline \multirow[t]{2}{*}{ Education $*$ gdp } & 0.023 & 0.0425 \\
\hline & $0.0094 *$ & $0.0097 * *$ \\
\hline \multirow[t]{2}{*}{ Log of real income } & 0.0872 & 0.1114 \\
\hline & $0.0332 *$ & $0.0269 * *$ \\
\hline \multirow[t]{2}{*}{ Upper social class } & 0.1212 & 0.077 \\
\hline & $0.0213 * *$ & $0.0133 * *$ \\
\hline \multirow[t]{2}{*}{ Neighborhood attachment } & -0.0614 & -0.0743 \\
\hline & $0.0305+$ & $0.0193 * *$ \\
\hline \multirow[t]{2}{*}{ Town attachment } & 0.0628 & 0.0629 \\
\hline & $0.0211 * *$ & $0.0206^{* *}$ \\
\hline \multirow[t]{2}{*}{ County attachment } & -0.0767 & -0.0767 \\
\hline & $0.0336^{*}$ & $0.0217 * *$ \\
\hline \multirow[t]{2}{*}{ Continent attachment } & 0.0216 & 0.048 \\
\hline & 0.0239 & $0.0170 *$ \\
\hline \multirow[t]{2}{*}{ National pride (2) } & -0.1518 & -0.1403 \\
\hline & $0.0256^{* *}$ & $0.0184 * *$ \\
\hline \multirow[t]{2}{*}{ National pride (3) } & -0.0697 & -0.0895 \\
\hline & $0.0235^{* *}$ & $0.0179 * *$ \\
\hline \multirow[t]{2}{*}{ National pride (4) } & -0.1969 & -0.1623 \\
\hline & $0.0199 * *$ & $0.0139 * *$ \\
\hline \multirow[t]{2}{*}{ Constant } & 2.6136 & 2.5462 \\
\hline & $0.4037 * *$ & $0.2420 * *$ \\
\hline Number of obs & 9696 & 9696 \\
\hline Adj. $R^{2}$ & 0.19 & 0.22 \\
\hline
\end{tabular}

Notes: Standard errors - adjusted for clustering on country - are presented under each estimated coefficient. + significant at $10 \%$; significant at $5 \%$; * significant at $1 \%$. See definitions of the variables at the end of Tables 4, 6 and 7 .

The basic specification is shown with and without country dummies. Note that the inclusion of country dummies does not greatly improve the overall fit of the regression. (The models in Table 8 are OLS specifications, so that we can interpret the $R^{2}$ in the usual fashion.) Even without the country dummies, our preferred specification explains almost a fifth (19\%) of the variation in trade attitudes in our sample. Inclusion of the country dummies raises the adjusted $R^{2}$ only to $22 \%$. In view of the complex nature of the issue at hand and the imperfections of our data, we consider this to be a fair level of success at explaining attitudes towards trade. 
At the beginning of the paper, we highlighted the important differences that exist across countries in average pro-trade orientation. How well does our preferred specification do in explaining these cross-country differences? One way of getting at this question is to compute the standard deviation of the country dummy variables estimated without controls and, next, with all the variables in our preferred specification. As in Krueger and Summers (1988), we adjust the raw standard deviations, which are upwardly biased due to sampling variation. ${ }^{39}$ We find that the adjusted standard deviation decreases from 0.9642 to 0.6775 when we switch from the specification with no controls (only country dummy variables) to the specification with both economic and non-economic determinants (regression (2), Table 8). What this indicates is that our preferred specification is fairly successful in explaining average differences in trade attitudes across countries.

Consider two specific cases, Poland and Sweden. In Poland's case, the average value of Trade Opinion is 0.90 points lower (on a 5-point scale) than in Germany. ${ }^{40}$ What accounts for the difference? We can apply the coefficient estimates in column (2) of Table 8 to country-level averages of the regressors to arrive at an approximate decomposition. Our results indicate that some $65 \%$ of the difference is explained by differences in comparative advantage - i.e., more individuals associate themselves with skill-based gains from trade in Germany than in Poland - more than $20 \%$ by greater nationalism/patriotism in Poland, and about $6 \%$ by the greater incidence of perceptions of low social status in Poland. In Sweden's case, the average value of Trade Opinion is 0.33 points smaller than in Germany. Since the patterns of comparative advantage and the skill distribution do not differ greatly in these two countries, the bulk (roughly $60 \%$ ) of the difference between Germany and Sweden is accounted for by greater cosmopolitanism in Germany and greater nationalism/patriotism in Sweden.

Non-economic determinants, in the form of socio-demographic background, values, identities, and attachments, play a very important role in explaining the variation in attitudes over trade. Using a linear specification (as in regression (2), Table 8), if we first consider a model with only economic variables (education, education $*$ gdp, $(\log )$ real income) and dummy variables, and we next introduce the non-economic variables (age, male, upper social class, neighborhood attachment, town attachment, county attachment, continent attachment, national pride (2), national pride (3), and national pride (4)) the increase in the $R^{2}$ is equal to 0.0667 (from a value of 0.1536 ). If we repeat the same steps reversing the order (first the non-economic variables plus dummy variables, next the economic ones), the $R^{2}$ increases by 0.0218 (from a value of 0.1985 ).

To conclude, attitudes to trade are shaped by a complex set of determinants, both economic and non-economic ones. Values and narrow self-interest both matter.

\footnotetext{
${ }^{39}$ We use Krueger and Summers $(1988)$ 's formula $S D(\delta) \approx \sqrt{\operatorname{var}(\hat{\delta})-\sum_{k=1}^{n} \hat{\sigma}_{k}^{2} / n}$, where $\delta$ are the true country effects, $\hat{\delta}$ are the estimated ones, $\hat{\sigma}_{k}^{2}$ is the standard error of $\hat{\delta}_{k}$ and $n$ is the number of countries. As in Krueger and Summers (1988), we do not adjust for covariance terms.

40 The average values of Trade Opinion are calculated restricting the sample to observations without missing values for the regressors in our preferred specification.
} 


\section{Acknowledgements}

The authors thank Pippa Norris for acquainting us with the ISSP data set, and the Ford and Rockefeller Foundations for financial support. Seminar participants at Harvard, Stanford, and Cornell have provided very useful comments. They also thank Gary Chamberlain and Jack Porter for valuable econometric advice, and Zoë McLaren for editorial assistance. Suggestions made by two anonymous referees and especially by Jörn-Steffen Pischke have substantially improved the paper.

\section{Appendix A. Sector classification: Description of the reclassification procedure}

Since in the ISSP survey there is no direct question about industry, we infer sector of employment from data on occupation. We use individual answers to two questions in the data set, one asking for occupation according to an international code (the 4-digit International Standard Classification of Occupations (ISCO) from 1968 and from 1988) and another one asking for occupation in terms of national codes. Individuals in each country give information about own occupation according to only one of the classifications (either ISCO 1968 or ISCO 1988 or according to a national classification). In particular, individuals' occupations from the following countries are coded according to ISCO 1968: Germany West, Germany East, USA, Austria, Norway, Bulgaria, New Zealand, Spain, Slovak Republic. The occupation codes of this group of countries are recoded all together. Respondents' occupations from the following countries are instead coded according to ISCO 1988: Hungary, Ireland, Czech Republic, Poland, Slovenia, Canada, Russia, Latvia. Again, we recode the occupation codes of this group of countries all together. Finally, respondents' occupations for Great Britain, Sweden, the Philippines, Italy, Netherlands and Japan follow national occupation codes. Data from Great Britain, Sweden and the Philippines are recoded individually. The national occupation codes for Italy, Netherlands and Japan cannot be reclassified, since they are not detailed enough.

We reclassify the occupation variables from the ISSP data set in order to match the coding in the World Trade Analyzer (WTA) data set, containing world trade flows from 1980 to 1997 . To classify industries, the WTA uses a slightly modified version of the Standard International Trade Classification (SITC), Revision 2. However, in the WTA CD-ROM, information is also available in a different format. Data is organized according to the 34 manufacturing industry basis used by the U.S. Bureau of Economic Analysis (BEA). This coding is quite similar to the U.S. Standard Industrial Classification. The WTA CD-ROM includes the annual bilateral trade values between all countries in the world in 1980-1997 according to this 34-industry classification. We use the BEA classification to recode the occupation variables in the ISSP data set and construct a new variable indicating the individual sector of employment. The 34 industries (plus one - Non-manufacturing - recoded as 35) are listed in Table 9. In order to obtain a more precise match between the ISSP occupation data and the BEA industry codes, we base the recoding on a very detailed description of the correspondence between BEA codes and SITC Revision 2 (four-digit level) codes (we used "Appendix 
Table 9

BEA (Bureau of Economic Analysis) 34 manufacturing industry codes

1. Grain, Mill and Bakery Products

2. Beverages

3. Tobacco Product

4. Other Food and Kindred Products

5. Apparel and Other Textile Products

6. Leather and Leather Products

7. Pulp, Paper and Board Mills

8. Other Paper and Allied Products

9. Printing and Publishing

10. Drugs

11. Soaps, Cleaners, and Toilet Goods

12. Agricultural Chemicals

13. Industrial Chemicals and Synthetics

14. Other Chemicals

15. Rubber Products

16. Miscellaneous Plastic Products

17. Primary Metal Industries, Ferrous

18. Primary Metal Industries, Nonferrous

19. Fabricated Metal Products

20. Farm and Garden Machinery

21. Construction, Mining, etc.

22. Computer and Office Equipment

23. Other Nonelectric Machinery

24. Household Appliances

25. Household Audio and Video, etc.

26. Electronic Components

27. Other Electrical Machinery

28. Motor Vehicles and Equipment

29. Other Transportation Equipment

30. Lumber, Wood, Furniture, etc.

31. Glass Products

32. Stone, Clay, Concrete, Gypsum, etc.

33. Instruments and Apparatus

34. Other Manufacturing

35. Non-Manufacturing (natural resources, etc.)

D: SITC Revision 2 codes used by Statistics Canada, WTA, and the corresponding BEA 34 manufacturing industry codes", from "World Trade Flows, 1980-1997", by Feenstra (2000)).

In addition to the 35 BEA industry codes, we create new codes as combinations of the original 35 codes. This is necessary since the occupation codes used in the ISSP data set are not always detailed enough to be matched to any single BEA code. See an extract from the 1968 ISCO classification in Table 10 and corresponding BEA codes, assigned by us, as an example of the reclassification.

For each of the 35 original BEA industries, we consider sector-specific exports and imports. For each new code, exports (imports) are obtained as sum of exports 
(imports) of the sectors used in the combination (so, for example, exports of sector 36 , which is the combination of sectors 17 and 18, are set equal to the sum of exports of sectors 17 and 18). We then average both exports and imports over the years 1990-1995.

Table 10

Extract from 1968 International Standard Classification of Occupations

1968 ISCO BEA code

Agricultural, animal husbandry and forestry workers, fishermen and hunters

60 Farm managers and supervisors

6000 Farm managers and supervisors

6001 Farm managers and supervisors (general)

1,4

6009 Farm managers

1,4

1,4

61 Farmers

6100 Farmers $\quad 1,4$

6110 General farmers $\quad 1,4$

6112 General farmers (general) 1,4

6115 Collective farmers 1,4

6120 Specialised farmers $\quad 1,4$

62 Agricultural and animal husbandry workers

6200 Agricultural and animal husbandry worker $\quad 1,4$

6210 General farm workers $\quad 1,4$

6211 Farm helpers (general) 1,4

6219 Farm hand $\quad 1,4$

6220 Field crop and vegetable farm workers $\quad 1,4$

6230 Orchard, vineyard and related tree and shrub crop workers 4

6240 Livestock workers $\quad 4$

6250 Dairy farm workers $\quad 4$

6260 Poultry farm workers $\quad 4$

6270 Nursery workers and gardeners 4

6280 Farm machinery operators $\quad 1,4$

6290 Agricultural and animal husbandry workers, n.e.c. $\quad 1,4$

63 Forestry workers

6300 Forestry workers

6310 Loggers 30

6319 Logger $\quad 30$

6320 Forestry workers (except logging) $\quad$ NT

64 Fishermen, hunters and related workers

6400 Fishermen, hunters and related workers 4

6410 Fishermen 4

6490 Fishermen, hunters and related workers, n.e.c. 4

Production and related workers, transport equipment operators and labourers

70 Production supervisors and general foremen

7000 Production supervisors and general foremen

m.v.

7001 Production supervisors and general foremen (general)

m.v. 
Table 10 (Continued)

1968 ISCO

BEA code

71 Miners, quarrymen, well drillers and related workers

7100 Miners, quarrymen, well drillers

7110 Miners and quarrymen $\quad 35$

7111 Quarrymen (general) $\quad 35$

7112 Cutting machine operators (mine) $\quad 35$

7119 Miners and related workers n.e.c. $\quad 35$

7120 Mineral and stone treaters $\quad 35$

7130 Well drillers, borers and related workers $\quad 35$

72 Metal processors

7200 Metal processors $\quad 17,18$

7210 Metal smelting, converting and refining furnacemen $\quad 17,18$

$\begin{array}{ll}7220 \text { Metal rolling-mill workers } & 17,18\end{array}$

$\begin{array}{ll}7230 \text { Metal melters and reheaters } & 17,18\end{array}$

7240 Metal casters $\quad 17,18$

7250 Metal moulders and coremakers $\quad 17,18$

7260 Metal annealers, temperers and case-hardeners $\quad 17,18$

7270 Metal drawers and extruders $\quad 17,18$

7280 Metal platers and coaters $\quad 17,18$

7290 Metal processers, n.e.c. $\quad 17,18$

73 Wood preparation workers and paper makers

$\begin{array}{ll}7300 \text { Wood preparation workers } & 30\end{array}$

7310 Wood treaters

7320 Sawyers, plywood makers and related wood-processing workers 30

7321 Sawmill sawyers (general) $\quad 30$

7330 Paper pulp preparers $\quad 7$

$\begin{array}{ll}7340 \text { Paper makers } & 7\end{array}$

74 Chemical processers and related workers

7400 Chemical processers and related workers 13

7410 Crushers, grinders and mixers 13

7420 Cookers, roasters and related heat-treaters 13

7430 Filter and separator operators $\quad 13$

7440 Still and reactor operators $\quad 13$

7450 Petroleum-refining workers $\quad 13$

7490 Chemical processers and related workers, n.e.c. 13

75 Spinners, weavers, knitters, dyers and related workers

7500 Spinners, weavers and related workers
7510 Fibre preparers

7520 Spinners and winders $\quad 5$

7530 Weaving- and knitting-machine setters and pattern-card preparers 5

7540 Weavers and related workers $\quad 5$

7550 Knitters $\quad 5$

7560 Bleachers, dyers and textile product finishers 5

7590 Spinners, weavers, knitters, dyers and related workers, n.e.c. 5

76 Tanners, fellmongers and pelt dressers

7600 Tanners, fellmongers and pelt dressers $\quad 6$

7610 Tanners and fellmongers $\quad 6$

7620 Pelt dressers $\quad 6$ 
Table 10 (continued)

1968 ISCO

BEA code

77 Food and beverage processers

7700 Food and beverage processers

7710 Grain millers

7720 Sugar processers and refiners

7730 Butchers and meat preparers

7740 Food preservers

7750 Dairy product processors

7760 Bakers, pastrycooks and confectionery makers 4

7770 Tea, coffee and cocoa preparers 2

7780 Brewers, wine and beverage makers 2

7790 Food and beverage processers, n.e.c. 2

78 Tobacco preparers and tobacco product makers

7810 Tobacco preparers 3

7820 Cigar makers

7830 Cigarette makers $\quad 3$

7890 Tobacco preparers and tobacco product makers, n.e.c. 3

79 Tailors, dressmakers, sewers, upholsterers and related workers

7900 Tailors, dressmakers, sewers and rel. workers $\quad 5$

7910 Tailors and dressmakers $\quad 5$

7919 Tailor $\quad 5$

7920 Fur tailors and related workers $\quad 5$

7930 Milliners and hatmakers $\quad 5$

7940 Patternmakers and cutters $\quad 5$

7950 Sewers and embroiderers $\quad 5$

7960 Upholsterers and related workers $\quad 5$

7990 Tailors, dressmakers, sewers, upholsterers and related workers, n.e.c. 5

80 Shoemakers and leather goods makers

8000 Shoemakers and leather good makers $\quad 6$

8010 Shoemakers and shoe repairers $\quad 6$

8020 Shoe cutters, lasters, sewers and related workers $\quad 6$

8030 Leather goods makers $\quad 6$

81 Cabinetmakers and related woodworkers

8100 Cabinetmakers and related woodworkers $\quad 30$

8110 Cabinetmakers $\quad 30$

8120 Woodworking-machine operators $\quad 30$

8190 Cabinetmakers and related woodworkers, n.e.c. $\quad 30$

82 Stone cutters and carvers

8200 Stone cutters and carvers

\section{Appendix B}

For ISSP data sets see Tables 11-14. 
Table 11

Demographic variables (ISSP data set)

\begin{tabular}{|c|c|c|c|c|c|c|c|c|c|c|c|c|c|c|c|c|c|}
\hline \multirow[t]{2}{*}{ Country } & \multirow{2}{*}{$\begin{array}{l}\text { Number of } \\
\text { observations } \\
\text { in the } \\
\text { sample }\end{array}$} & \multirow[t]{2}{*}{ Age } & \multirow{2}{*}{$\begin{array}{l}\text { Average } \\
\text { years of } \\
\text { education }\end{array}$} & \multirow[t]{2}{*}{ Male } & \multirow[t]{2}{*}{ Rural } & \multirow{2}{*}{$\begin{array}{l}\text { Trade } \\
\text { union } \\
\text { member- } \\
\text { ship }\end{array}$} & \multicolumn{6}{|c|}{ Upper social class } & \multicolumn{5}{|c|}{ Political affiliation with the right } \\
\hline & & & & & & & Lower & Working & $\begin{array}{l}\text { Lower } \\
\text { middle }\end{array}$ & Middle & $\begin{array}{l}\text { Upper } \\
\text { middle }\end{array}$ & Upper & $\begin{array}{l}\text { Far } \\
\text { left }\end{array}$ & $\begin{array}{l}\text { Centre } \\
\text { left }\end{array}$ & Centre & Right & $\begin{array}{l}\text { Far } \\
\text { right }\end{array}$ \\
\hline Germany West & 1282 & 46 & 10.93 & 0.54 & - & 0.36 & 2.03 & 0.00 & 16.15 & 56.40 & 16.54 & 1.25 & 0.31 & 48.99 & 5.46 & 35.96 & 2.57 \\
\hline Germany East & 612 & 48 & 10.93 & 0.50 & - & 0.78 & 8.99 & 0.00 & 33.50 & 43.14 & 4.25 & 0.33 & 15.20 & 43.46 & 5.07 & 25.49 & 1.31 \\
\hline Great Britain & 1058 & 47 & 11.34 & 0.40 & - & 0.21 & - & - & - & - & - & - & 0.57 & 42.91 & 14.56 & 26.28 & 0.00 \\
\hline USA & 1367 & 45 & 13.43 & 0.44 & 1.59 & 0.10 & 5.85 & 45.79 & 0.00 & 44.33 & 0.00 & 3.29 & 0.00 & 34.31 & 36.06 & 27.65 & 0.00 \\
\hline Austria & 1007 & 46 & 10.39 & 0.45 & - & 0.46 & 3.67 & 0.00 & 15.49 & 61.77 & 12.51 & 0.79 & 0.00 & 36.15 & 4.47 & 29.89 & 0.00 \\
\hline Hungary & 1000 & 48 & 10.50 & 0.43 & 1.97 & 0.15 & 12.70 & 35.20 & 25.30 & 22.20 & 1.20 & 0.00 & - & - & - & - & - \\
\hline Italy & 1094 & 43 & 11.03 & 0.48 & 1.98 & 0.12 & 1.37 & 0.00 & 11.52 & 71.30 & 13.35 & 2.47 & - & - & - & - & - \\
\hline Ireland & 994 & 46 & 12.26 & 0.49 & 2.02 & 0.26 & 1.61 & 35.31 & 14.29 & 38.73 & 4.33 & 0.50 & 0.00 & 2.41 & 35.41 & 0.91 & 0.00 \\
\hline Netherlands & 2089 & 44 & 12.69 & 0.46 & 1.72 & 0.21 & - & - & - & - & - & - & 6.46 & 18.00 & 25.99 & 15.65 & 2.73 \\
\hline Norway & 1527 & 43 & 12.68 & 0.50 & 2.09 & 0.44 & 0.00 & 30.39 & 6.48 & 39.49 & 8.32 & 0.52 & 0.65 & 38.11 & 18.60 & 19.71 & 0.00 \\
\hline Sweden & 1296 & 45 & 11.43 & 0.49 & 1.23 & 0.71 & 2.39 & 35.19 & 0.00 & 45.06 & 9.18 & 0.69 & 5.79 & 33.33 & 13.97 & 17.98 & 0.00 \\
\hline Czech Republic & 1111 & 43 & 12.91 & 0.51 & 1.65 & 0.21 & 4.14 & 27.27 & 21.24 & 35.01 & 6.39 & 1.26 & 5.13 & 10.80 & 39.33 & 22.59 & 9.00 \\
\hline Slovenia & 1036 & 43 & 10.68 & 0.44 & 2.03 & 0.35 & 3.28 & 34.07 & 0.00 & 47.49 & 6.18 & 0.19 & 0.00 & 4.54 & 9.56 & 17.37 & 1.93 \\
\hline Poland & 1598 & 47 & 10.29 & 0.45 & 1.72 & 0.13 & 7.38 & 41.24 & 0.00 & 39.55 & 4.44 & 2.19 & 0.00 & 24.16 & 9.26 & 4.69 & 0.00 \\
\hline Bulgaria & 1105 & 49 & - & 0.48 & 1.92 & 0.19 & 14.57 & 51.67 & 0.00 & 26.24 & 0.00 & 1.00 & 5.97 & 15.02 & 8.05 & 8.96 & 2.71 \\
\hline Russia & 1585 & 45 & 11.19 & 0.45 & 1.50 & 0.32 & 12.81 & 29.72 & 14.64 & 25.11 & 2.90 & 0.69 & 18.30 & 3.15 & 8.08 & 35.84 & 4.35 \\
\hline New Zealand & 1043 & 46 & 14.33 & 0.47 & 1.50 & 0.15 & 3.36 & 18.98 & 10.64 & 40.94 & 11.79 & 0.96 & 0.00 & 4.22 & 55.23 & 4.89 & 0.00 \\
\hline Canada & 1543 & 42 & 14.78 & 0.49 & 1.16 & 0.20 & 2.59 & 16.40 & 10.17 & 31.82 & 13.09 & 1.49 & 0.91 & 20.03 & 30.07 & 14.58 & 0.00 \\
\hline Philippines & 1200 & 40 & 9.38 & 0.50 & 1.75 & 0.01 & 25.08 & 61.33 & 0.00 & 10.83 & 0.00 & 2.75 & - & - & - & - & - \\
\hline Japan & 1256 & 46 & 11.87 & 0.46 & - & 0.13 & 4.46 & 0.00 & 19.27 & 48.65 & 17.20 & 3.50 & 1.67 & 5.18 & 6.21 & 24.12 & 0.00 \\
\hline Spain & 1221 & 45 & 10.13 & 0.48 & 1.48 & 0.08 & 6.14 & 41.28 & 17.61 & 28.75 & 3.77 & 0.33 & 11.47 & 31.37 & 0.25 & 28.58 & 0.00 \\
\hline Latvia & 1044 & 47 & 11.64 & 0.39 & 0.39 & 0.19 & 11.88 & 43.30 & 20.98 & 0.00 & 9.77 & 0.57 & - & - & - & - & - \\
\hline Slovak Republic & 1388 & 41 & 11.83 & 0.48 & - & 0.32 & 8.65 & 30.98 & 21.97 & 26.59 & 6.63 & 1.66 & 4.90 & 13.18 & 35.81 & 12.68 & 6.41 \\
\hline Mean & 28,456 & 44.77 & 11.69 & 0.47 & 1.69 & 0.31 & 7.29 & 30.77 & 12.45 & 40.15 & 7.90 & 1.44 & 6.07 & 33.16 & 28.97 & 29.28 & 2.52 \\
\hline Standard Deviation & & 16.88 & 3.58 & 0.50 & 0.90 & 0.46 & & & & & & & & & & & \\
\hline
\end{tabular}

Male is coded as follows: 1 male, 0 otherwise (i.e., 0 includes m.v.).

Trade Union Membership is coded as follows: 1 member, 0 otherwise (i.e., 0 includes m.v.).

Both Upper Social Class and Political Affiliation with the Right give percentages of individuals belonging to each category, over the whole national sample (i.e., including m.v.). 
Table 12

Attachment to own neighborhood, town/city and county/region and national pride variables (ISSP data set)

\begin{tabular}{|c|c|c|c|c|c|c|c|c|c|c|c|c|c|c|}
\hline \multirow{3}{*}{$\begin{array}{l}\text { Country } \\
\\
\text { Germany }\end{array}$} & \multicolumn{14}{|c|}{$\%$ in each nation declaring } \\
\hline & \multicolumn{2}{|c|}{$\begin{array}{l}\text { Attachment } \\
\text { to own } \\
\text { neighborhood } \\
\text { (neighborhood } \\
\text { attachment) }\end{array}$} & \multicolumn{2}{|c|}{$\begin{array}{l}\text { Attachment } \\
\text { to own } \\
\text { town/city } \\
\text { (town } \\
\text { attachment) }\end{array}$} & \multicolumn{2}{|c|}{$\begin{array}{l}\text { Attachment } \\
\text { to own } \\
\text { county/region } \\
\text { (country } \\
\text { attachment) }\end{array}$} & \multicolumn{2}{|c|}{$\begin{array}{l}\text { Attachment } \\
\text { to own } \\
\text { country } \\
\text { (national } \\
\text { pride }(1) \text { ) }\end{array}$} & \multicolumn{2}{|c|}{$\begin{array}{l}\text { "rather be } \\
\text { citizen of own } \\
\text { country" } \\
\text { (national } \\
\text { pride (2)) }\end{array}$} & \multicolumn{2}{|c|}{$\begin{array}{l}\text { Own country } \\
\text { better than } \\
\text { others } \\
\text { (national } \\
\text { pride (3)) }\end{array}$} & \multicolumn{2}{|c|}{$\begin{array}{l}\text { In favor of } \\
\text { country's interests } \\
\text { at any cost } \\
\text { (national } \\
\text { pride (4)) }\end{array}$} \\
\hline & 0.74 & 12 & 0.72 & 7 & 0.68 & 7 & 0.80 & 4 & 0.69 & 3 & 0.37 & 8 & 0.29 & 5 \\
\hline Great Britain & 0.64 & 3 & 0.56 & 1 & 0.51 & 2 & 0.71 & 2 & 0.73 & 8 & 0.56 & 13 & 0.52 & 16 \\
\hline USA & 0.57 & 2 & 0.60 & 2 & 0.62 & 4 & 0.81 & 5 & 0.91 & 22 & 0.81 & 21 & 0.44 & 13 \\
\hline Austria & 0.83 & 16 & 0.84 & 16 & 0.89 & 20 & 0.91 & 13 & 0.86 & 15 & 0.69 & 17 & 0.62 & 20 \\
\hline Hungary & 0.80 & 14 & 0.84 & 15 & 0.86 & 18 & 0.96 & 22 & 0.87 & 17 & 0.26 & 3 & 0.41 & 10 \\
\hline Italy & 0.68 & 8 & 0.82 & 12 & 0.80 & 16 & 0.87 & 10 & 0.62 & 2 & 0.37 & 7 & 0.30 & 6 \\
\hline Ireland & 0.84 & 17 & 0.83 & 14 & 0.81 & 17 & 0.93 & 15 & 0.86 & 16 & 0.71 & 18 & 0.63 & 21 \\
\hline Netherlands & 0.71 & 10 & 0.71 & 5 & 0.49 & 1 & 0.87 & 9 & 0.50 & 1 & 0.46 & 11 & 0.28 & 4 \\
\hline Norway & 0.51 & 1 & 0.70 & 4 & 0.79 & 15 & 0.94 & 20 & 0.78 & 11 & 0.67 & 16 & 0.38 & 9 \\
\hline Sweden & 0.65 & 4 & 0.66 & 3 & 0.66 & 6 & 0.83 & 7 & 0.70 & 5 & 0.48 & 12 & 0.44 & 12 \\
\hline Czech Republic & 0.81 & 15 & 0.87 & 19 & 0.69 & 9 & 0.92 & 14 & 0.73 & 7 & 0.22 & 1 & 0.31 & 7 \\
\hline Slovenia & 0.77 & 13 & 0.82 & 13 & 0.78 & 14 & 0.93 & 17 & 0.78 & 13 & 0.28 & 4 & 0.28 & 3 \\
\hline Poland & 0.73 & 11 & 0.75 & 9 & 0.64 & 5 & 0.94 & 19 & 0.88 & 19 & 0.39 & 9 & 0.48 & 15 \\
\hline Bulgaria & 0.88 & 21 & 0.89 & 21 & 0.86 & 19 & 0.93 & 16 & 0.88 & 20 & 0.57 & 14 & 0.73 & 22 \\
\hline Russia & 0.67 & 6 & 0.72 & 6 & 0.62 & 3 & 0.82 & 6 & 0.75 & 9 & 0.42 & 10 & 0.61 & 19 \\
\hline New Zealand & 0.65 & 5 & 0.76 & 10 & 0.71 & 11 & 0.94 & 18 & 0.81 & 14 & 0.78 & 20 & 0.52 & 17 \\
\hline Canada & 0.69 & 9 & 0.76 & 11 & 0.74 & 13 & 0.74 & 3 & 0.78 & 12 & 0.77 & 19 & 0.43 & 11 \\
\hline Philippines & 0.86 & 19 & 0.73 & 8 & 0.68 & 8 & 0.68 & 1 & 0.88 & 18 & 0.59 & 15 & 0.37 & 8 \\
\hline Japan & 0.91 & 22 & 0.88 & 20 & 0.89 & 21 & 0.95 & 21 & 0.89 & 21 & 0.84 & 22 & 0.19 & 1 \\
\hline Spain & 0.88 & 20 & 0.92 & 22 & 0.90 & 22 & 0.89 & 12 & 0.73 & 6 & 0.36 & 6 & 0.61 & 18 \\
\hline Latvia & 0.68 & 7 & 0.85 & 18 & 0.69 & 10 & 0.86 & 8 & 0.76 & 10 & 0.32 & 5 & 0.44 & 14 \\
\hline Slovak Republic & 0.84 & 18 & 0.85 & 17 & 0.73 & 12 & 0.89 & 11 & 0.69 & 4 & 0.23 & 2 & 0.23 & 2 \\
\hline Mean & 0.74 & & 0.78 & & 0.73 & & 0.87 & & 0.78 & & 0.51 & & 0.43 & \\
\hline Standard deviation & 0.11 & & 0.10 & & 0.12 & & 0.08 & & 0.10 & & 0.20 & & 0.15 & \\
\hline
\end{tabular}


Notes: The second column of each variable gives the ranking of countries according to that variable. Bold numbers correspond to highest and lowest values. Neighborhood attachment gives responses to the following question: "How close do you feel to (respondent's neighbourhood)?" Town attachment gives responses to the following question: "How close do you feel to (respondent's town/city)?" County attachment gives responses to the following question: "How close do you feel to (respondent's county)?" National pride (1) gives responses to the following question: "How close do you feel to (respondent's country)?". National pride (2) gives responses to the question: "How much do you agree or disagree with the following statements? I would rather be a citizen of (respondent's country) than of any other country in the world." National pride (3) gives responses to the question: "How much do you agree or disagree with the following statements? Generally (respondent's country) is a better country than most other countries." National pride (4) gives responses to the question: "How much do you agree or disagree with the following statements? (respondent's country) should follow its own interests, even if this leads to conflicts with other nations." 
Table 13

Pride in specific achievements (ISSP data set)

\begin{tabular}{|c|c|c|c|c|c|c|c|c|}
\hline \multirow{3}{*}{$\begin{array}{l}\text { Country } \\
\text { Germany }\end{array}$} & \multicolumn{8}{|c|}{$\%$ in each nation declaring } \\
\hline & \multicolumn{2}{|c|}{$\begin{array}{l}\text { Proud of } \\
\text { national } \\
\text { democracy }\end{array}$} & \multicolumn{2}{|c|}{$\begin{array}{l}\text { Proud of political } \\
\text { influence } \\
\text { in the world }\end{array}$} & \multicolumn{2}{|c|}{$\begin{array}{l}\text { Proud } \\
\text { of economic } \\
\text { achievements }\end{array}$} & \multicolumn{2}{|c|}{$\begin{array}{l}\text { Proud of } \\
\text { social security } \\
\text { system }\end{array}$} \\
\hline & 0.57 & 12 & 0.61 & 16 & 0.83 & 22 & 0.62 & 17 \\
\hline Great Britain & 0.68 & 15 & 0.55 & 15 & 0.44 & 12 & 0.48 & 12 \\
\hline USA & 0.83 & 20 & 0.80 & 22 & 0.82 & 19 & 0.50 & 13 \\
\hline Austria & 0.71 & 16 & 0.63 & 17 & 0.82 & 21 & 0.84 & 22 \\
\hline Hungary & 0.20 & 1 & 0.18 & 1 & 0.09 & 1 & 0.07 & 1 \\
\hline Italy & 0.26 & 6 & 0.23 & 3 & 0.40 & 9 & 0.28 & 8 \\
\hline Ireland & 0.75 & 18 & 0.79 & 21 & 0.82 & 20 & 0.65 & 19 \\
\hline Netherlands & 0.84 & 21 & 0.49 & 13 & 0.78 & 16 & 0.83 & 21 \\
\hline Norway & 0.80 & 19 & 0.78 & 19 & 0.80 & 18 & 0.62 & 16 \\
\hline Sweden & 0.64 & 13 & 0.41 & 11 & 0.17 & 3 & 0.65 & 18 \\
\hline Czech Republic & 0.35 & 8 & 0.51 & 14 & 0.42 & 11 & 0.19 & 6 \\
\hline Slovenia & 0.21 & 3 & 0.29 & 4 & 0.34 & 8 & 0.30 & 9 \\
\hline Poland & 0.24 & 5 & 0.36 & 6 & 0.28 & 6 & 0.17 & 4 \\
\hline Bulgaria & 0.31 & 7 & 0.36 & 7 & 0.26 & 5 & 0.18 & 5 \\
\hline Russia & 0.20 & 1 & 0.32 & 5 & 0.16 & 2 & 0.08 & 2 \\
\hline New Zealand & 0.73 & 17 & 0.71 & 18 & 0.72 & 15 & 0.39 & 10 \\
\hline Canada & 0.84 & 22 & 0.79 & 20 & 0.62 & 14 & 0.81 & 20 \\
\hline Philippines & 0.53 & 10 & 0.39 & 9 & 0.50 & 13 & 0.52 & 14 \\
\hline Japan & 0.66 & 14 & 0.45 & 12 & 0.80 & 17 & 0.47 & 11 \\
\hline Spain & 0.54 & 11 & 0.40 & 10 & 0.41 & 10 & 0.53 & 15 \\
\hline Latvia & 0.40 & 9 & 0.38 & 8 & 0.21 & 4 & 0.12 & 3 \\
\hline Slovak Republic & 0.22 & 4 & 0.19 & 2 & 0.31 & 7 & 0.22 & 7 \\
\hline Mean & 0.52 & & 0.48 & & 0.50 & & 0.43 & \\
\hline Standard deviation & 0.24 & & 0.20 & & 0.26 & & 0.25 & \\
\hline
\end{tabular}

Notes: The second column of each variable gives the ranking of countries according to that variable. Bold numbers correspond to highest and lowest values. Pride in democracy answers the following question:: "How proud are you of (respondent's country) in each of the following? The way democracy works." Pride in political influence answers the following question: : "How proud are you of (respondent's country) in each of the following? Political influence in world." Economic pride answers the following question: : "How proud are you of (respondent's country) in each of the following? Economic achievements." Pride in social security system answers the following question: : "How proud are you of (respondent's country) in each of the following? Social security system."

Table 14

Per capita GDP of the countries in the ISSP and WVS samples

\begin{tabular}{lcc}
\hline Country & $\begin{array}{l}\text { Per capita GDP in } 1995 \\
\text { (PPP-adjusted) }\end{array}$ & $\begin{array}{l}\text { Log of per capita GDP in } \\
1995 \text { (PPP-adjusted) }\end{array}$ \\
\hline Nigeria & 824.990 & 6.715 \\
Bangladesh & 1280.880 & 7.155 \\
Ghana & 1709.830 & 7.444 \\
Pakistan & 1765.360 & 7.476 \\
India & 1871.220 & 7.534 \\
Armenia & 1938.330 & 7.570
\end{tabular}


Table 14 (continued)

\begin{tabular}{|c|c|c|}
\hline Country & $\begin{array}{l}\text { Per capita GDP in } 1995 \\
\text { (PPP-adjusted) }\end{array}$ & $\begin{array}{l}\text { Log of per capita GDP in } \\
1995 \text { (PPP-adjusted) }\end{array}$ \\
\hline Azerbaijan & 1982.220 & 7.592 \\
\hline Georgia & 2016.160 & 7.609 \\
\hline Moldova & 2403.020 & 7.784 \\
\hline China & 2681.390 & 7.894 \\
\hline Philippines & 3633.240 & 8.198 \\
\hline Ukraine & 3811.710 & 8.246 \\
\hline Macedonia & 4299.560 & 8.366 \\
\hline Dominican Republic & 4350.740 & 8.378 \\
\hline Peru & 4419.710 & 8.394 \\
\hline Latvia & 5037.370 & 8.525 \\
\hline Belarus & 5217.670 & 8.560 \\
\hline Lithuania & 5626.700 & 8.635 \\
\hline Bulgaria & 5679.510 & 8.645 \\
\hline Croatia & 5905.530 & 8.684 \\
\hline Turkey & 5924.610 & 8.687 \\
\hline Colombia & 6012.530 & 8.702 \\
\hline Venezuela & 6019.300 & 8.703 \\
\hline Romania & 6543.390 & 8.786 \\
\hline Estonia & 6558.690 & 8.789 \\
\hline Brazil & 6726.440 & 8.814 \\
\hline Poland & 6794.980 & 8.824 \\
\hline Russia & 7206.220 & 8.883 \\
\hline Mexico & 7221.970 & 8.885 \\
\hline Chile & 7733.390 & 8.953 \\
\hline Uruguay & 8017.480 & 8.989 \\
\hline S. Africa & 8631.180 & 9.063 \\
\hline Slovakia & 8667.670 & 9.067 \\
\hline Hungary & 9577.070 & 9.167 \\
\hline Argentina & 10940.100 & 9.300 \\
\hline Czech Republic & 12414.290 & 9.427 \\
\hline Slovenia & 13191.210 & 9.487 \\
\hline S. Korea & 13758.830 & 9.529 \\
\hline Portugal & 13774.940 & 9.531 \\
\hline Spain & 15412.220 & 9.643 \\
\hline Ireland & 17844.910 & 9.789 \\
\hline Finland & 19204.450 & 9.863 \\
\hline Britain & 19880.390 & 9.897 \\
\hline Sweden & 20449.570 & 9.926 \\
\hline Italy & 20888.240 & 9.947 \\
\hline France & 21065.020 & 9.955 \\
\hline Netherlands & 21087.570 & 9.956 \\
\hline Australia & 21562.500 & 9.979 \\
\hline Germany & 22029.480 & 10.000 \\
\hline Austria & 22672.040 & 10.029 \\
\hline Belgium & 22892.860 & 10.039 \\
\hline Iceland & 23305.430 & 10.056 \\
\hline Canada & 23487.480 & 10.064 \\
\hline Denmark & 23527.680 & 10.066 \\
\hline Japan & 23725.340 & 10.074 \\
\hline Norway & 25336.920 & 10.140 \\
\hline Switzerland & 25964.120 & 10.164 \\
\hline USA & 28173.420 & 10.246 \\
\hline
\end{tabular}

Source: World Development Indicators CD-ROM (World Bank). 


\section{References}

Alesina, A., La Ferrara, E., 2001. Preferences for redistribution in the land of opportunities. NBER Working Paper W8267.

Alesina, A., Di Tella, R., MacCulloch, R., 2001. Inequality and happiness: Are Europeans and Americans different? NBER Working Paper W8198.

Alston, R.M., Kearl, J.R., Vaughan, M.B., 1992. Is there a consensus among economists in the 1990's? The American Economic Review 82 (2); Papers and Proceedings of the Hundred and Fourth Annual Meeting of the American Economic Association, pp. 203-209.

Baldwin, R.E., Magee, C.S., 1998. Is trade policy for sale? congressional voting on recent trade bills. NBER Working Paper W6376.

Balistreri, E.J., 1997. The performance of the Heckscher-Ohlin-Vanek model in predicting endogenous policy forces at the individual level. Canadian Journal of Economics 30 (1), 1-17.

Barro, R., Lee, J., 1996. International data on educational attainment. Data set.

Barro, R., Lee, J., 2000. International data on educational attainment. Data set.

Beaulieu, E., 1996. Who supported the Canada-U.S. free trade agreement: Factor or industry cleavages in trade policy? University of Calgary.

Beaulieu, E., Magee, C.S., 2001. Campaign contributions and trade policy: New tests of Stolper-Samuelson, University of Calgary.

Beaulieu, E., Benarroch, M., Gaisford, J., 2003. Intra-industry trade liberalization: Why skilled workers resist protectionism, University of Calgary.

Blanchflower, D.G., Oswald, A.J., 2000. Well-Being over Time in Britain and the USA.

Caplan, B., 2001. Systematically biased beliefs about economics. Center for the Study of Public Choice, George Mason University.

Card, D., 1996. The effect of unions on the structure of wages: A longitudinal analysis. Econometrica 64 (4), 957-979.

Feenstra, R.C., 2000. World Trade Flows. 1980-1997 plus data CD.

Inglehart, R., 1997. World Value Surveys and European Values Surveys, 1981-1984, 1990-1993, and 19951997 [computer file], ICPSR version, Institute for Social Research [producer], Interuniversity Consortium for Political and Social Research [distributor].

International Social Survey Programme, 1995. National Identity.

Irwin, D.A., 1994. The political economy of free trade: Voting in the British general elections of 1906. Journal of Law and Economics 37, 75-108.

Irwin, D.A., 1996. Industry or class cleavages over trade policy? Evidence from the British general election of 1923. In: Feenstra, R.C., Grossman, G.M., Irwin, D.A. (Eds.), The Political Economy of Trade Policy: Papers in Honor of Jagdish Bhagwati. The MIT Press, Cambridge, MA, pp. 53-75.

Krueger, A.B., Summers, L.H., 1988. Efficiency wages and the inter-industry wage structure. Econometrica 56 (2), 259-293.

Luttmer, E.F.P., 2001. Group loyalty and the taste for redistribution. Journal of Political Economy 109 (3), $500-528$.

Magee, S.P., 1978. Three simple tests of the Stolper-Samuelson theorem. In: Oppenheimer, P. (Ed.), Issues in International Economics. Oriel Press, Stockfield.

Mayer, W., 1984. Endogenous tariff formation. American Economic Review 74, 970-985.

Midford, P., 1993. International trade and domestic politics: Improving on Rogowski's model of political alignments. International Organization 47 (4), 535-564.

O'Rourke, K.H., Sinnott, R., 2001. What determines attitudes towards protection? Some cross-country evidence. In: Collins, S.M., Rodrik, D. (Eds.), Brookings Trade Forum 2001. Brookings Institute Press, Washington DC, pp. 157-206.

Rodrik, D., 1995. Political economy of trade policy. In: Grossman, G., Rogoff, K. (Eds.), Handbook of International Economics, Vol. 3. Elsevier Science Publishers, Amsterdam, pp. 1457-1494.

Rogowski, R., 1987. Political cleavages and changing exposure to trade. American Political Science Review 81 (4), 1121-1137. 
Rogowski, R., 1989. Commerce and Coalitions. Princeton University Press, Princeton, NJ.

Scheve, K.F., Slaughter, M.J., 2001a. What determines individual trade policy preferences? Journal of International Economics 54 (2), 267-292.

Scheve, K.F., Slaughter, M.J., 2001b. Globalization and the Perceptions of American Workers. Institute for International Economics, Washington DC.

Smith, T.W., Jarkko, L., 1998. National pride: A cross-national analysis. GSS Cross-national Report 19. 